Check for updates

Cite this: Anal. Methods, 2018, 10, 1219

\title{
Raman spectroscopic library of medieval pigments collected with five different wavelengths for investigation of illuminated manuscripts $\dagger$
}

\author{
G. Marucci, (D) ${ }^{a}$ A. Beeby, (D) ${ }^{b}$ A. W. Parker (D) ${ }^{c}$ and C. E. Nicholson (iD) *a
}

Raman spectroscopy is widely applied in the cultural heritage field to perform non-destructive measurements in situ, in order to identify materials, specifically pigments. The spectra collected can be challenging to interpret because certain source laser wavelengths may be absorbed by specific pigments, leading to large fluorescence backgrounds which obscure the weak Raman signals, or worse cause photodegradation of the sample. Furthermore, the reference spectra for a specific pigment obtained from a particular laser wavelength is not always available and is a crucial step in the detective work of pigment identification, especially when the resonance Raman effect can enhance some signals. As the range of lasers available increases, spectral libraries do not always record spectra acquired with the same wavelength used to carry out the measurements in field. In this work, reference spectra of 32 different compounds, mostly used in mediaeval manuscripts as pigments and inks, are recorded. Five different wavelengths were used as excitation sources. The aim is to provide a useful and more complete reference source to enable better planning of which laser wavelength is the most appropriate to study a specific set of pigments, and to allow comparisons between spectra acquired with the same wavelength, leading to the unequivocal pigment identification in a step by step manner.

Received 3rd January 2018
Accepted 10th February 2018

DOI: 10.1039/c8ay00016f

rsc.li/methods

\section{Introduction}

The use of analytical techniques for the study of objects of historical and artistic interest has increased in the last thirty years, providing useful information about artists' techniques, the provenance of materials, the nature of degradation processes, ${ }^{1}$ authentication and dating. The priceless nature of works of art has driven scientists to employ non-invasive and non-destructive techniques. This, coupled with the high insurance values of the articles, essentially prevents the analysis of objects in host laboratories: work has to be done within the conservation studios of the host institution. Over the past decade, this has been achieved with the advent of portable, instrumentation that can be taken to the host libraries or institutions for in situ investigations on the fly. Among the different techniques that are routinely employed for the analysis of artefacts or manuscripts, micro-Raman spectroscopy has proven to be an extremely powerful, due to its portability, specificity,

\footnotetext{
${ }^{a}$ Northumbria University, Applied Sciences, Newcastle upon Tyne, NE1 8ST, UK. E-mail: k.nicholson@northumbria.ac.uk

${ }^{b}$ Durham University, Chemistry Department, DH1 3LE, UK

${ }^{c}$ Central Laser Facility, Research Complex at Harwell, STFC Rutherford Appleton Laboratory, Harwell Campus, Didcot, OX11 OQX, UK

$\dagger$ Electronic supplementary information (ESI) available: Figures of pigments spectra, from 1 to 30 ; the data of the Raman spectra collected at the different wavelengths. See DOI: 10.1039/c8ay00016f
}

spatial resolution and non-contact, non-destructive nature..$^{2-31}$ The first effective application of Raman spectroscopy on cultural heritage objects was on illuminated manuscripts to identify pigments, ${ }^{32}$ and it has since been used to study a wide variety of materials including paper, ${ }^{33}$ binder media, ${ }^{34}$ inks, ${ }^{35,36}$ glass, ${ }^{5,9,10,18}$ ceramics and pottery, ${ }^{7,8}$ gemstones, ${ }^{20}$ stones and rocks from archaeological sites, ${ }^{\mathbf{1 9 , 3 0}}$ degradation products. ${ }^{3}$ The availability of a spectral library is therefore essential to help identify the materials deployed. ${ }^{34,37-39}$ A few portable Raman spectrometers are now commercially available, but these should be used with extreme caution: in many examples, the power of the laser light source is much higher than we would advocate and may cause damage to the artefact. Furthermore, commercially available portable instruments usually have a single laser source, in rare cases two, which are not necessarily the best ones to investigate the wide variety of pigments that can be found on the same artefact, positive identifications can often be difficult. ${ }^{26,31}$ Indeed, pigments respond differently to laser irradiation according to their nature (dyes or pigments, colour, etc.). In certain cases, for example, where the laser wavelength matches or is close to the absorption bands of the pigment being analysed, the Resonance Raman effect can lead to excellent sensitivity, but, in some cases, some absorption can also lead to large interfering, luminescent background signals which hide the low intensity Raman signals. The selection of the most appropriate wavelength for the identification of pigments then is of great interest and importance. 
Portable equipment means compromises have to be made in comparison with fixed laboratory equipment. Portable systems tend to sacrifice spectral resolution and sensitivity. ${ }^{31}$ This work provides an updated library of pigments' Raman spectra acquired using different laser wavelengths in order to supply the best spectrum possible for each pigment for comparison to the data collected in situ. The pigments have been chosen as representative of those used in illuminated manuscripts between Vth-XVIth centuries in Europe. ${ }^{32,36,40-67}$

\section{Experimental}

\section{Instrumentation}

Two different Raman spectrometers have been used, equipped with different lasers. The first was a Horiba Jobin Yvon LabRAM HR confocal Raman microscope, equipped with a Peltier-cooled CCD and $50 \times$ LWD Leica objective. The instrument has four different laser sources available, $488 \mathrm{~nm}, 532 \mathrm{~nm}, 632.8 \mathrm{~nm}$ and $785 \mathrm{~nm}$ providing a diffraction limited laser spot from 1 to $2 \mu \mathrm{m}$ diameter. Each laser source has different maximum power values that can be reduced using neutral density filter $(100 \%$ $50 \%, 25 \%, 10 \%, 1 \%, 0.1 \%$ and $0.01 \%$ ). Reported laser powers were measured after the objective lens in the sample plane. A $6001 \mathrm{~mm}^{-1}$ grating was used for measurements using the $532 \mathrm{~nm}, 632.8 \mathrm{~nm}$ and $785 \mathrm{~nm}$ laser, and an $1800 \mathrm{l} \mathrm{mm}^{-1}$ grating used for the $488 \mathrm{~nm}$ laser. The minimum wavenumber for each laser wavelength, dictated by the edge filters in the spectrometer were $200 \mathrm{~cm}^{-1}, 120 \mathrm{~cm}^{-1}, 70 \mathrm{~cm}^{-1}, 100 \mathrm{~cm}^{-1}$ respectively for the $488 \mathrm{~nm}, 532 \mathrm{~nm}, 632.8 \mathrm{~nm}$ and $785 \mathrm{~nm}$ lasers. All the acquisition operations were controlled by Lab Spec 6-Horiba Scientific software.

For excitation at $830 \mathrm{~nm}$, a Renishaw InVIa micro-Raman spectrometer (Rutherford Appleton Laboratory, Harwell Campus, Didcot), with $830 \mathrm{~nm}$ laser source, a silicon CCD detector and Nikon L-PLAN SLWD $50 \times / 0.45$. The resulting laser spot was circa $2 \mu \mathrm{m}$ in diameter. The spectral range recorded was $70-1800 \mathrm{~cm}^{-1}$, with a $1200 \mathrm{l} \mathrm{mm}^{-1}$ grating. The maximum laser power was $55 \mathrm{~mW}$, and this could be reduced to lower levels $(50 \%, 25 \%, 10 \%, 5 \%, 1 \%, 0.5 \%, 0.1 \%$ and $0.05 \%)$. Again, the laser power was recorded after the objective in the sample plane.

A silicon standard sample was used as reference for calibration $\left(520 \mathrm{~cm}^{-1}\right)$. The time of acquisitions and number of accumulations was decided on a sample-by-sample basis.

To be able to compare spectra acquired with different devices, spectra were corrected for the instrumental response by comparison to the spectra obtained for a broad-band source. ${ }^{68,69}$ A stable white light source (HL-2000-CAL Ocean Optics), whose spectral distribution was known (and can be approximated by a black body radiator of $2939 \mathrm{~K}$ ), was used to generate a correction curve. The lamp emission spectrum was provided as photons $/(\Delta \lambda t)$, where $\Delta \lambda$ is the bandwidth detected by the spectrometer, and $t$ the time unit. It had to be multiplied by $\lambda^{2}$ (where $\lambda$ is the emission wavelength), in order to obtain the spectrum in terms of photons $/ t \times \Delta \bar{u}$ of Raman shift. The calibration lamp spectrum was recorded for every wavelength laser using the same scan-conditions as used for the sample measurements and covering the same wavenumber range. Using this correction curve, all of the Raman spectra were corrected for instrument response. No background subtraction was performed, since one of the goals of this work was to provide a library that helps to decide which the best wavelength to investigate a certain pigment is, so any luminescent background that may detract from the signal or prove diagnostic was recorded. All the spectra have been normalized to a maximum intensity of 1 in the graphs (Fig. 1-30) available in the ESI (ESI $\dagger$ ). In the ESI, $\dagger$ the raw ASCII data of the spectra can be found. Corrected for the instrument response. Thus, relative intensities of peaks may be obtained and compared directly.

\section{Classification of the spectra}

A classification of the quality of the spectra collected (Table 1) was made, in order to establish the optimum wavelength for investigating the presence of a specific pigment, and which wavelength provides the maximum number of positive identifications. To classify them, a criterion to value the quality of the spectrum had to be established and the signal to noise ratio was considered appropriate. Even though this parameter is meaningful if applied to a single peak or band it does not give an evaluation of the whole spectrum, since to identify a Raman spectrum a "finger printing" approach is often used; analysing the most intense peak and then the following less intense ones to confirm or refute the identification. In this study only the signal to noise ratio of highest peak of every spectrum was used to evaluate the whole spectrum. However, spectra showing only one peak were not included because a single peak is insufficient to unequivocally identify a pigment. $^{70}$ In spectroscopy, the signal to noise ratio, SNR, is defined as

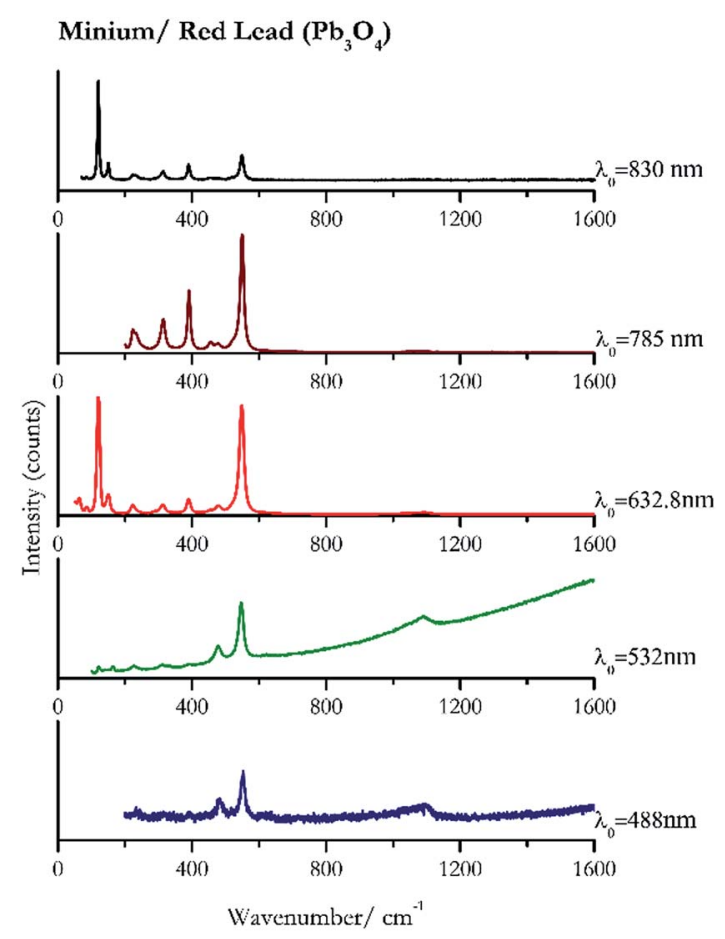

Fig. 1 Raman spectra of minium or red lead. 
Table 1 Classification of the spectra. ++ very good spectrum; + = good spectrum; $\pm=$ spectrum with peaks but pigment not identifiable; $-=$ no spectrum

\begin{tabular}{|c|c|c|c|c|c|}
\hline Pigment & $488 \mathrm{~nm}$ & $532 \mathrm{~nm}$ & $632.8 \mathrm{~nm}$ & $785 \mathrm{~nm}$ & $830 \mathrm{~nm}$ \\
\hline Minium & + & + & ++ & ++ & ++ \\
\hline Haematite & \pm & + & + & + & ++ \\
\hline Red ochre & + & + & + & + & + \\
\hline Caput mortuum & + & + & + & ++ & ++ \\
\hline Vermillion & + & + & ++ & ++ & ++ \\
\hline Cinnabar & + & + & ++ & ++ & ++ \\
\hline Realgar & - & \pm & ++ & ++ & ++ \\
\hline Kermes & - & - & - & - & - \\
\hline Cochineal & \pm & + & - & + & - \\
\hline Orcein & + & + & + & + & + \\
\hline Brazil wood & - & - & - & - & - \\
\hline Purple madder & + & + & + & + & + \\
\hline Alizarin crimson & + & \pm & + & + & + \\
\hline Alizarin purple & + & - & - & + & + \\
\hline Raw umber & \pm & + & \pm & - & + \\
\hline Sepia & - & + & + & + & + \\
\hline Indigo & \pm & + & + & + & ++ \\
\hline Azurite & + & + & + & + & + \\
\hline Ultramarine & + & ++ & + & + & + \\
\hline Orpiment & + & ++ & ++ & ++ & ++ \\
\hline Lead tin yellow I & ++ & ++ & ++ & ++ & ++ \\
\hline Yellow ochre & + & + & + & + & ++ \\
\hline Massicot & ++ & ++ & ++ & ++ & ++ \\
\hline Gamboge & + & \pm & - & + & + \\
\hline White lead & + & + & ++ & ++ & ++ \\
\hline Verdigris & + & + & + & \pm & + \\
\hline Malachite & + & + & + & - & + \\
\hline Carbon black & + & + & + & \pm & + \\
\hline Ivory black & + & + & + & + & + \\
\hline Lamp black & + & + & + & + & + \\
\hline Iron gall & - & + & - & \pm & \pm \\
\hline Bistre & + & \pm & + & + & + \\
\hline
\end{tabular}

$$
\mathrm{SNR}=\frac{I}{\sigma}
$$

where $I$ is the average intensity (net peak height - background) of the signal and $\sigma$ is its standard deviation. ${ }^{71}$ However, the noise is the result of different sources. So that

$$
\sigma=\sqrt{ }\left(\sigma_{\mathrm{s}}^{2}+\sigma_{\mathrm{b}}^{2}+{\sigma_{\mathrm{d}}}^{2}+{\sigma_{\mathrm{r}}}^{2}\right)
$$

where $\sigma_{\mathrm{s}}$ is the uncertainty of the measurements known as signal shot noise. $\sigma_{\mathrm{b}}$ is the noise due to the background, that includes fluorescence of the sample and stray light. $\sigma_{\mathrm{d}}$ is the noise generated by the dark current of the detector and the $\sigma_{\mathrm{r}}$ is the readout noise caused by the conversion from the electronic signal to a digital value in the CCD camera (and subsequent transfer from the detector to the computer). ${ }^{71}$ The signal shot noise is the square root of the signal intensity according to the Poisson statistic, since the emission and detection of photons are random event. ${ }^{72,73}$ However, background and the dark noise are detected in the same way as the Raman signal and similarly they are equal to the square root of the background intensity and dark current ${ }^{71}$ respectively. Finally, the read out noise is the standard deviation of the numerical value the electrons from the detector device are converted into when digitized. ${ }^{71}$ Thus, the overall signal to noise ratio is defined as

$$
\mathrm{SNR}=\frac{I}{\sqrt{\left(\sigma_{\mathrm{s}}{ }^{2}+\sigma_{\mathrm{b}}{ }^{2}+\sigma_{\mathrm{d}}{ }^{2}+\sigma_{\mathrm{r}}{ }^{2}\right)}}
$$

To calculate the signal to noise ratio, the contribution of the dark noise and the read out noise were considered negligible, which is appropriate for the scientific grade CCD camera employed in the spectrometers, while the background noise was the result of the square root of the difference of intensities between the spectra before and after background correction. A peak may be defined as at least 2 or 3 times the intensity of the noise. ${ }^{70,72}$ So that the spectra were classified as "very good" spectrum (++) when the SNR > 100; "good spectrum" $(+)$ when 3 $<$ SNR < 100; "spectrum not identifiable" $( \pm)$ when SNR $<3$ and/ or the spectrum presented only one peak; "no spectrum" $(-)$ when no spectrum at all was recorded.

\section{Materials}

Pigments and inks investigated were both pigments and dyes, chosen in accordance with the literature, most commonly used in manuscripts between Vth-XVIth centuries, supplied by L. Cornelissen \& Son (London) and Kremer Pigmente GmbH \& Co. KG (Aichstetten, Germany). Iron gall ink, Brazil wood and kermes were made following ancient recipes. ${ }^{74}$ Analysis of pure pigments using the $532 \mathrm{~nm}$ and $632.8 \mathrm{~nm}$ lasers was made by sampling through the wall of a glass vial containing the pigments. Indeed, the use of a confocal microscope allows collecting radiation coming only from the focal plane, so that there is no signal related to the glass. ${ }^{72}$ However, using the $785 \mathrm{~nm}$ excitation source the spectra presented a large background at around $1400 \mathrm{~cm}^{-1}$ (ref. 75) so pellets of pigments were prepared to obtain Raman spectra without glass contribution. The measurements performed with $488 \mathrm{~nm}$ and $830 \mathrm{~nm}$ excitation were also run on pellets. They were prepared by pressing a mixture of the pigment and a $10 \% \mathrm{w} / \mathrm{w}$ of a wax binder, (BM-0002-1CEREOX ${ }^{\circledR}$ Licowax C Micropowder). To ensure the homogeneity of the samples the mixture of wax and pigment was shaken for 3 minutes with a frequency of $25 \mathrm{~s}^{-1}$, and pellets were then formed using a hydraulic press, with 9 tonnes per surface pressure. The spectra collected do not show any signals attributable to the wax.

\section{Results and discussion}

A total of 32 pigments have been analysed using 5 different incident wavelength laser sources. The spectra are represented in Fig. 1-30 (in the ESI $\dagger$ ). They are ordered by observed colour (red, purple, blue, yellow, white, green, black and inks). In Table 1 the positive identifications are summarized. Tables 2 to 6 list the wavenumber of the main peaks detected, with references from previous works, ${ }^{37-39,76-81}$ where spectra have been reported for similar conditions. Each table refers to a single wavelength laser source. The first column provides the highest observed peak in the measured spectral range for that wavelength. In the 
Table 2 Characteristic peaks of Raman spectra of pigments acquired with a $488 \mathrm{~nm}$ excitation source. Broad bands are labelled with "br", shoulder bands are labelled with "sh"

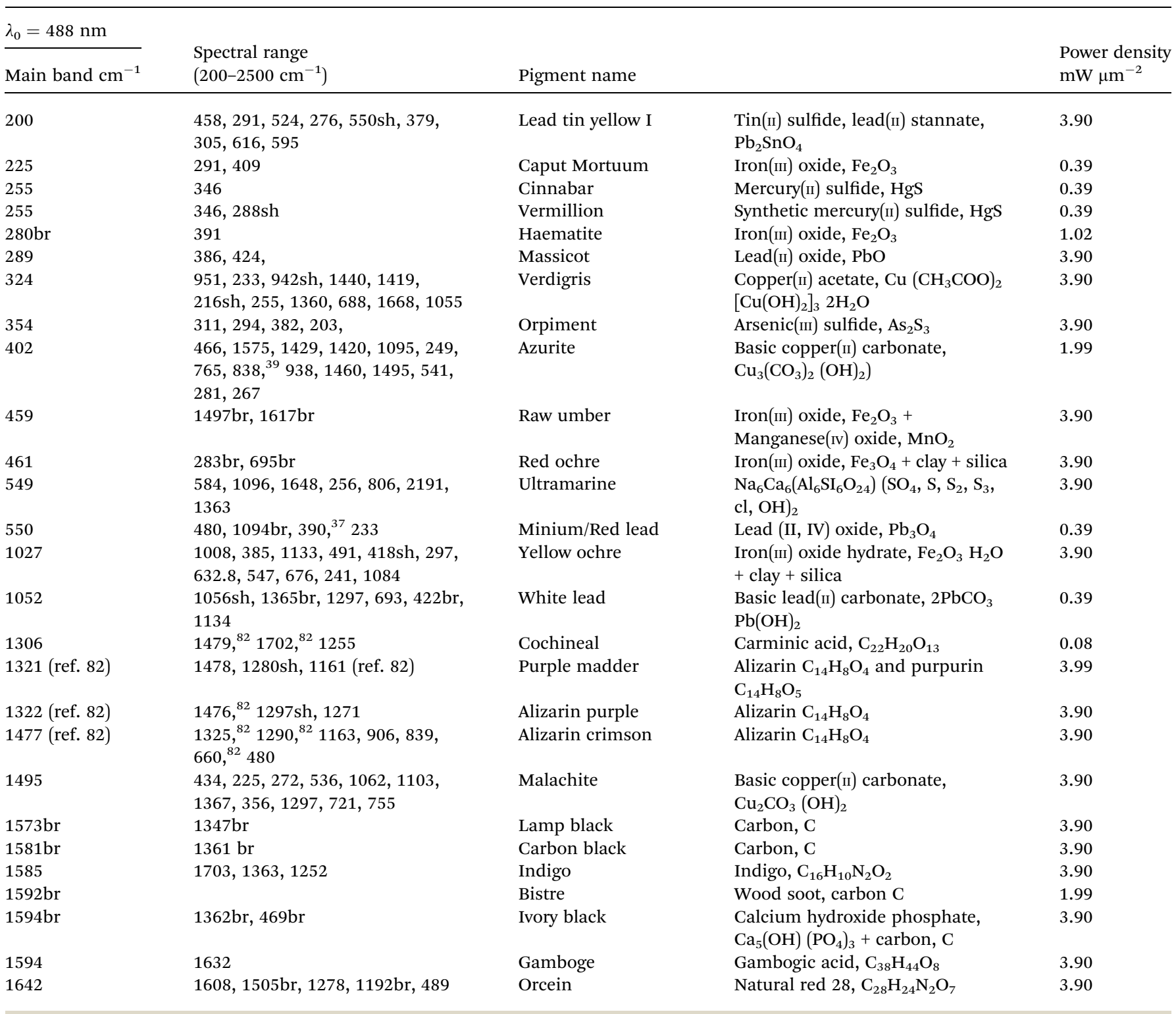

second column the other peaks, in decreasing order of intensity, can be found; in the other columns the name and the compounds of the pigment. In the last column, the values of power density are recorded.

To use the library:

(1) Select the table pertinent to the laser wavelength used to carry out the measurements;

(2) Look for the highest intensity peak in the first column;

(3) Check the other peaks in the second column. The third column provides the name of the pigment.

\section{Red pigments}

For convenience, the pigments can be divided into two major groups. The first is the iron oxide compounds (haematite, red ochre and caput mortuum, which belongs also to the inks group as well), and the others (cinnabar, vermillion, minium/red lead). All the iron oxide (Fig. 2-4) compounds show the main peaks at around $223 \mathrm{~cm}^{-1}$, between $290 \mathrm{~cm}^{-1}$, around $407 \mathrm{~cm}^{-1}$, but only the spectra acquired with $532 \mathrm{~nm}$ and the $632.8 \mathrm{~nm}$ excitation beams show an intense peak between $1316 \mathrm{~cm}^{-1}$ and $1323 \mathrm{~cm}^{-1}$. The intensity enhancement is attributed to resonance effects since the absorption edge for $\mathrm{Fe}_{2} \mathrm{O}_{3}$ is at $580 \mathrm{~nm}$. Spectra acquired with $488 \mathrm{~nm}$ all have poor signals, because of absorption by the pigment. Unfortunately, the red ochre (Fig. 3), which is a mixture of iron oxides, clays and silica, is the one that provided lowest signal to noise ratio with all the laser sources compared to haematite and caput mortuum. The red ochre spectra are indeed affected by fluorescence, likely related to the presence of a heterogeneous matrix. In the second group, minium (Fig. 1), or red lead, is a lead oxide, whose the main peak resulting from $632.8 \mathrm{~nm}$ 
Table 3 Characteristic peaks of Raman spectra of pigments acquired with a $532 \mathrm{~nm}$ excitation source (a) range between 100 and $2500 \mathrm{~cm}^{-1}$, (b) range between 108 and $2500 \mathrm{~cm}^{-1}$, (c) range between $150-2500 \mathrm{~cm}^{-1}$. Broad bands are labelled with "br", shoulder bands are labelled with "sh"

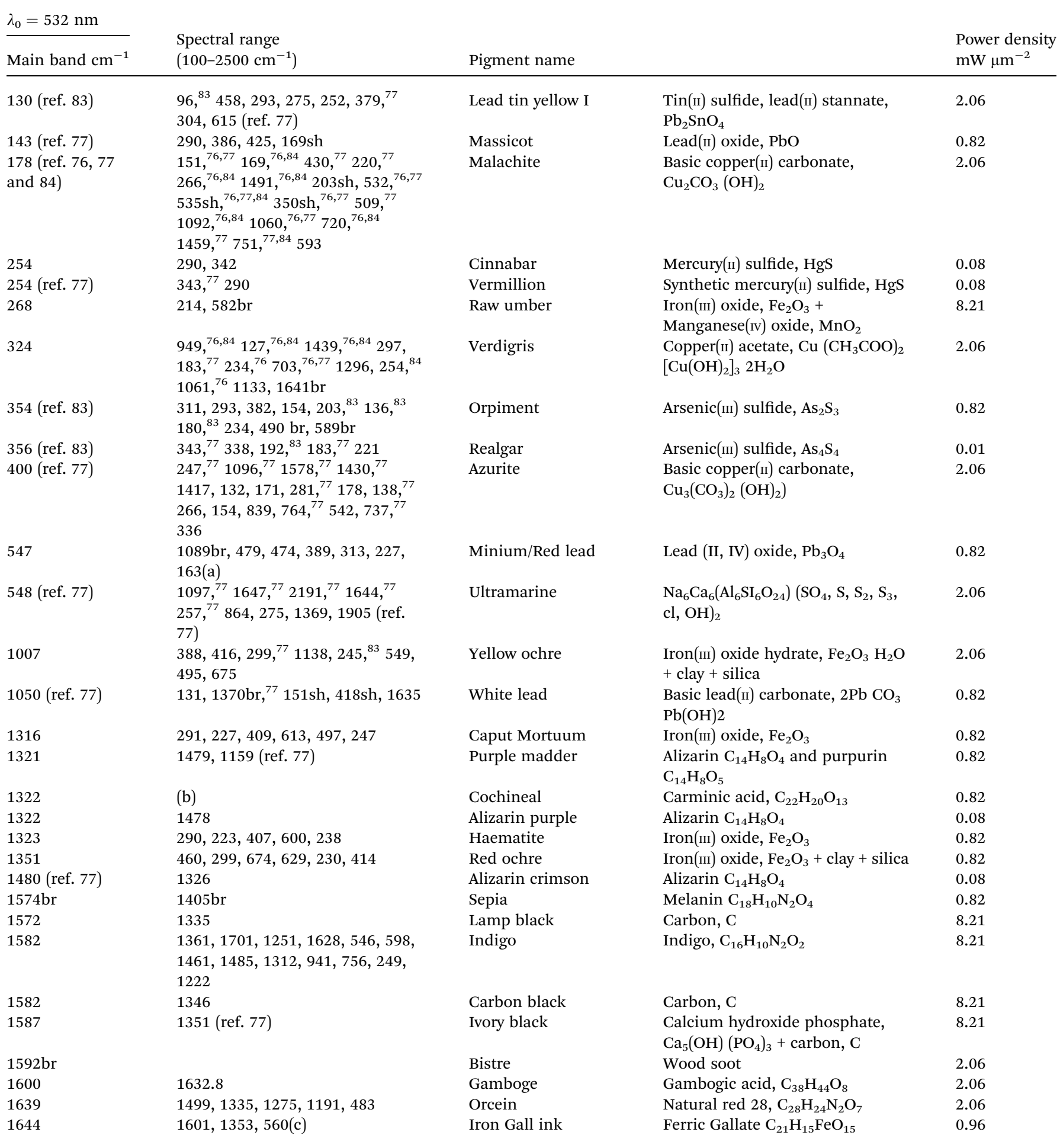

excitation is at $121 \mathrm{~cm}^{-1}$, due to the deformation of the $\mathrm{O}-\mathrm{Pb}-\mathrm{O}$ angle. This was not detectable with the other wavelengths because of the edge filters cutting off low wavenumbers or attenuating the signal, and in literature studies of manuscripts this band is often omitted for this reason. However, contrary to the report by Burgio et al. ${ }^{1}$ who reported sample damage when using $488 \mathrm{~nm}$ and $514.5 \mathrm{~nm}$ radiations, it was possible to detect the pigment thanks to a low power density at $0.39 \mathrm{~mW} \mu \mathrm{m}^{-2}$. Cinnabar and vermillion (Fig. 5 and 6) are the mineral and synthetic forms of mercury sulphide, both show indeed the same very strong peak at 251-255 $\mathrm{cm}^{-1}$. They are both detectable with all the five wavelengths, and only low laser power is 
Table 4 Characteristic peaks of Raman spectra of pigments acquired with a $632.8 \mathrm{~nm}$ excitation source. (a) Range between 80 and $2500 \mathrm{~cm}^{-1}$, (b) range between 50 and $2500 \mathrm{~cm}^{-1}$. Broad bands are labelled with "br", shoulder bands are labelled with "sh"

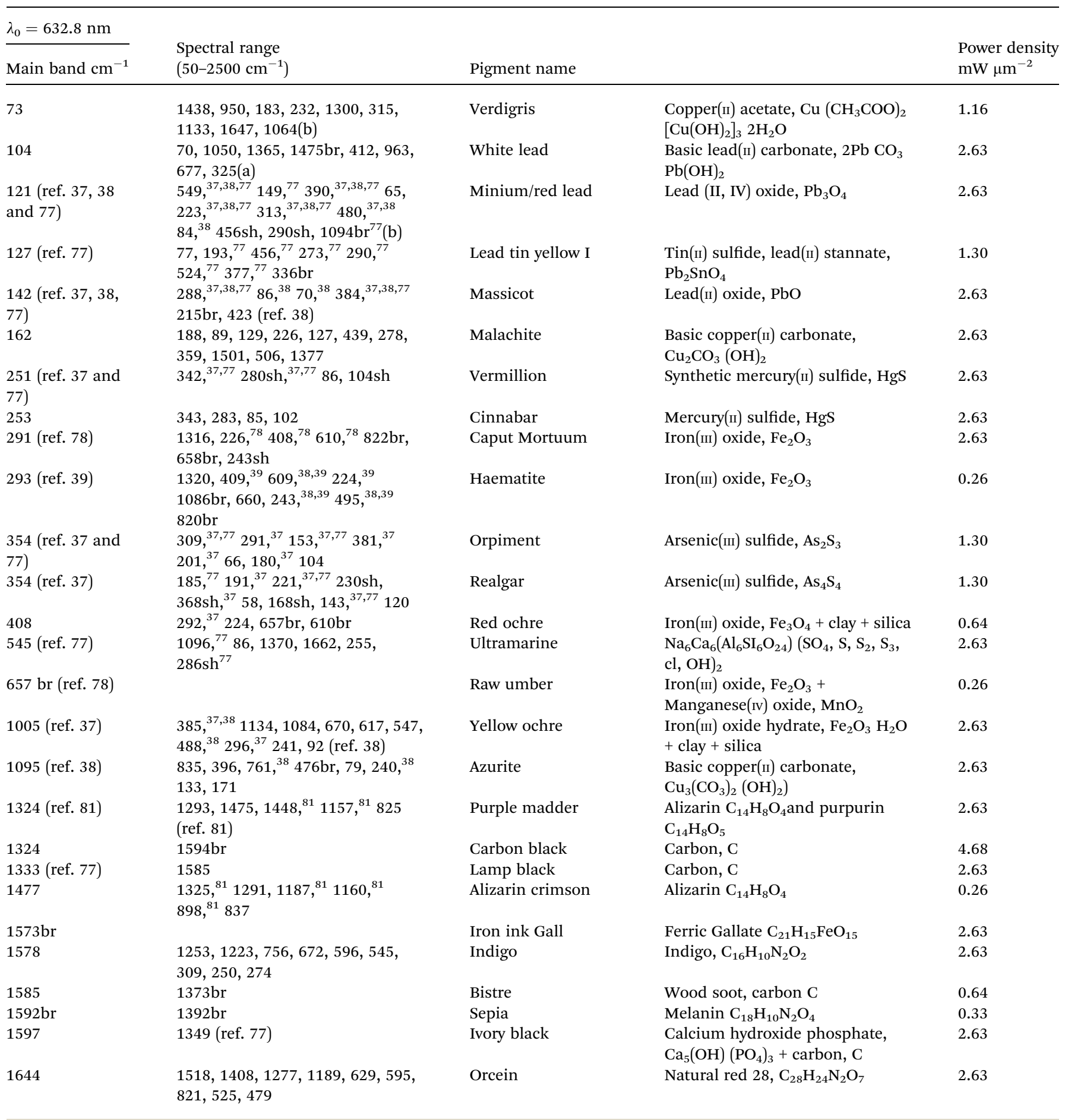

required when working with $532 \mathrm{~nm}$ and $488 \mathrm{~nm}$ lasers to prevent saturation of the detector even at short acquisition times. Realgar is a photosensitive mineral ${ }^{95}$ and its transformation to pararealgar occurred using the $532 \mathrm{~nm}$ and the 488 $\mathrm{nm}$ wavelength laser source. Unfortunately the minimum power level for both the configurations was sufficient for this transformation and good spectra were not obtained without damaging the sample (Fig. 7).

\section{Purple pigments}

Cochineal (Fig. 8), orcein (Fig. 9), brazil wood, kermes, purple madder (Fig. 10), alizarin crimson (Fig. 11) and alizarin purple (Fig. 12) are all organic compounds and, these spectra are prone to be affected by fluorescence depending on the wavelength of the excitation source. The spectrum collected with the $830 \mathrm{~nm}$ and $632.8 \mathrm{~nm}$ of cochineal does not show any Raman bands. 
Table 5 Characteristic peaks of Raman spectra of pigments acquired with a $785 \mathrm{~nm}$ excitation source. (a) Range between $200-2500 \mathrm{~cm}^{-1}$. Broad bands are labelled with "br", shoulder bands are labelled with "sh"

\begin{tabular}{|c|c|c|c|c|}
\hline \multirow{2}{*}{$\frac{\lambda_{0}=785 \mathrm{~nm}}{\text { Main band } \mathrm{cm}^{-1}}$} & \multirow[b]{2}{*}{ Spectral range $\left(100-2500 \mathrm{~cm}^{-1}\right)$} & \multirow[b]{2}{*}{ Pigment name } & & \multirow{2}{*}{$\begin{array}{l}\text { Power } \\
\text { density W } \\
\mu \mathrm{m}^{-2}\end{array}$} \\
\hline & & & & \\
\hline 549 (ref. 77) & $\begin{array}{l}391,314,,^{77} 224,,^{77} 234 \mathrm{sh}, 456, \\
480(\text { a) }\end{array}$ & Minium/red lead & Lead (II, IV) oxide, $\mathrm{Pb}_{3} \mathrm{O}_{4}$ & 3.58 \\
\hline 107 & $\begin{array}{l}1051,{ }^{77} 1055 \mathrm{sh}, 410,320 \mathrm{br}, 679,{ }^{77} \\
1136,1441,1640\end{array}$ & White lead & $\begin{array}{l}\text { Basic lead(II) carbonate, } 2 \mathrm{~Pb} \mathrm{CO}_{3} \\
\mathrm{~Pb}(\mathrm{OH})_{2}\end{array}$ & 3.58 \\
\hline 129 (ref. 77) & $\begin{array}{l}196,,^{77} 457,,^{77} 291,,^{77} 274,111, \\
524,{ }^{77} 379,,^{77} 337,508,304,337, \\
\text { 432sh }\end{array}$ & Lead tin yellow I & $\begin{array}{l}\text { Tin(II) sulfide, lead(II) stannate, } \\
\mathrm{Pb}_{2} \mathrm{SnO}_{4}\end{array}$ & 3.58 \\
\hline 142 (ref. 77) & $288,^{77} 384,,^{77} 214,427$ & Massicot & Lead(II) oxide, PbO & 3.58 \\
\hline 223 (ref. 77) & $290,{ }^{77} 406$ (ref. 77) & Red ochre & Iron(III) oxide, $\mathrm{Fe}_{3} \mathrm{O}_{4}+$ clay + silica & 3.58 \\
\hline 253 & $343,286,107,143$ & Vermillion & Synthetic mercury(II) sulfide, HgS & 0.96 \\
\hline 254 & $343,287,108,143,201$ & Cinnabar & Mercury(II) sulfide, HgS & 0.32 \\
\hline 290 & $408,224,244,609,498,1323 \mathrm{br}$ & Haematite & Iron(III) oxide, $\mathrm{Fe}_{2} \mathrm{O}_{3}$ & 3.58 \\
\hline 290 & $224,407,609,244,495,1316$ & Caput mortuum & Iron(III) oxide, $\mathrm{Fe}_{2} \mathrm{O}_{3}$ & 3.58 \\
\hline 353 (ref. 77) & $\begin{array}{l}292,202,{ }^{77} 383,325,218,472,585, \\
653,706\end{array}$ & Orpiment & Arsenic(III) sulfide, $\mathrm{As}_{2} \mathrm{~S}_{3}$ & 3.58 \\
\hline 354 (ref. 77) & $\begin{array}{l}192,,^{77} 181,220,343,,^{77} 142,,^{77} 165, \\
171,{ }^{77} 368,374,328,212\end{array}$ & Realgar & Arsenic(III) sulfide, $\mathrm{As}_{4} \mathrm{~S}_{4}$ & 0.96 \\
\hline 397 & $\begin{array}{l}246,464,128,1095,1428,762 \\
834,1574\end{array}$ & Azurite & $\begin{array}{l}\text { Basic copper(II) carbonate, } \\
\left.\mathrm{Cu}_{3}\left(\mathrm{CO}_{3}\right)_{2}(\mathrm{OH})_{2}\right)\end{array}$ & 3.58 \\
\hline 482 & $\begin{array}{l}1274,1188,,^{90} 592,,^{90} 524,,^{90} 809, \\
1463,1492,1640 \text { (ref. } 90 \text { ) }\end{array}$ & Orcein & Natural red $28, \mathrm{C}_{28} \mathrm{H}_{24} \mathrm{~N}_{2} \mathrm{O}_{7}$ & 3.58 \\
\hline 550 (ref. 77) & $584 \mathrm{sh},{ }^{77} 256$ & Ultramarine & $\begin{array}{l}\mathrm{Na}_{6} \mathrm{Ca}_{6}\left(\mathrm{Al}_{6} \mathrm{SI}_{6} \mathrm{O}_{24}\right)\left(\mathrm{SO}_{4}, \mathrm{~S}, \mathrm{~S}_{2}, \mathrm{~S}_{3},\right. \\
\mathrm{cl}, \mathrm{OH})\end{array}$ & 3.58 \\
\hline 980 & $1430,1338,573 \mathrm{br}$ & Iron gall ink & Ferric Gallate $\mathrm{C}_{21} \mathrm{H}_{15} \mathrm{FeO}_{15}$ & 4.94 \\
\hline 1007 & $\begin{array}{l}1255,1224,384,431,1138,495, \\
1410,671\end{array}$ & Yellow ochre & $\begin{array}{l}\text { Iron(III) oxide hydrate, } \mathrm{Fe}_{2} \mathrm{O}_{3} \mathrm{H}_{2} \mathrm{O} \\
+ \text { clay + silica }\end{array}$ & 3.58 \\
\hline $1248 \mathrm{br}$ & $1560 \mathrm{br}$ & Bistre & Wood soot, carbon C & 4.94 \\
\hline 1293 & $1318,,^{90} 1442$ & Purple madder & $\begin{array}{l}\text { Alizarin } \mathrm{C}_{14} \mathrm{H}_{8} \mathrm{O}_{4} \text { and purpurin } \\
\mathrm{C}_{14} \mathrm{H}_{8} \mathrm{O}_{5}\end{array}$ & 3.58 \\
\hline 1303 (ref. 90) & $1321,,^{77} 1473$ & Cochineal & Carminic acid, $\mathrm{C}_{22} \mathrm{H}_{20} \mathrm{O}_{13}$ & 3.58 \\
\hline $1350 \mathrm{br}$ & $1550 \mathrm{br}$ & Sepia & Melanin $\mathrm{C}_{18} \mathrm{H}_{10} \mathrm{~N}_{2} \mathrm{O}_{4}$ & 3.58 \\
\hline 1430 & 1136,227 & Verdigris & $\begin{array}{l}\text { Copper(II) acetate, } \mathrm{Cu}\left(\mathrm{CH}_{3} \mathrm{COO}\right)_{2} \\
{\left[\mathrm{Cu}(\mathrm{OH})_{2}\right]_{3} 2 \mathrm{H}_{2} \mathrm{O}}\end{array}$ & 3.58 \\
\hline 1431 & 1584,1304 & Lamp black & Carbon, C & 3.58 \\
\hline 1474 & 1302, 1323 (ref. 90) & Alizarin purple & Alizarin $\mathrm{C}_{14} \mathrm{H}_{8} \mathrm{O}_{4}$ & 3.58 \\
\hline 1480 (ref. 90) & $\begin{array}{l}1328,1292,,^{77} 480,1192,1462 \mathrm{sh}, \\
1451 \mathrm{sh}^{90} 841,1163,{ }^{77,90} 659,904 \\
\text { (ref. } 77 \text { and } 90 \text { ) }\end{array}$ & Alizarin crimson & Alizarin $\mathrm{C}_{14} \mathrm{H}_{8} \mathrm{O}_{4}$ & 3.58 \\
\hline 1571 & $\begin{array}{l}1580 \mathrm{sh}, 250,545,,^{77} 597,,^{77} 262, \\
674,,^{77} 273,756,{ }^{77} 1223,1308, \\
1459,1362,1015 \text { (ref. } 77 \text { ) }\end{array}$ & Indigo & Indigo, $\mathrm{C}_{16} \mathrm{H}_{10} \mathrm{~N}_{2} \mathrm{O}_{2}$ & 3.58 \\
\hline 1576 & 1332 & Carbon black & Carbon, $\mathrm{C}$ & 3.58 \\
\hline 1585 (ref. 77) & 1329 & Ivory black & $\begin{array}{l}\text { Calcium hydroxide phosphate, } \\
\mathrm{Ca}_{5}(\mathrm{OH})\left(\mathrm{PO}_{4}\right)_{3}+\text { carbon, } \mathrm{C}\end{array}$ & 3.58 \\
\hline 1592 (ref. 77) & 1297, 1620sh, 1136, 1062 & Gamboge & Gambogic acid, $\mathrm{C}_{38} \mathrm{H}_{44} \mathrm{O}_{8}$ & 3.58 \\
\hline
\end{tabular}

Orcein, purple madder and alizarin crimson were detectable with all the wavelengths, while alizarin purple did not provide any spectrum with the $532 \mathrm{~nm}$ (absorption at $530 \mathrm{~nm}$ ) and $632.8 \mathrm{~nm}$ radiation. For kermes and brazil wood, no spectra could be obtained at any of the five laser wavelengths.

\section{Blue pigments}

Indigo (Fig. 14) provides better spectra with the NIR and IR laser since it possesses a broad absorption band in the visible range ${ }^{85}$ However, it is still possible to recognise the pigment, thanks to the peak at $1580 \mathrm{~cm}^{-1}$ circa and $545 \mathrm{~cm}^{-1}$ also with lower wavelengths, which are superimposed upon the weak fluorescence from this material. Azurite (Fig. 15) yields a good spectrum with all the wavelengths except the $632.8 \mathrm{~nm}$ laser source, attributed to the strong absorption by the pigment at $c a$. $600 \mathrm{~nm}$. When using the infrared sources at 785 and $830 \mathrm{~nm}$, a very low energy (785 $\mathrm{nm}$ and $830 \mathrm{~nm}, 3.58$ and $8.69 \mathrm{~mW} \mu \mathrm{m}^{-2}$ ) was used: at higher levels absorption of the radiation and localised heating of the sample results in its degradation. When 
Table 6 Characteristic peaks of Raman spectra of pigments acquired with a $532 \mathrm{~nm}$ excitation source. (a) Range between $100-2500 \mathrm{~cm}^{-1}$. Broad bands are labelled with "br", shoulder bands are labelled with "sh"

\begin{tabular}{|c|c|c|c|c|}
\hline \multicolumn{5}{|l|}{$\lambda_{0}=830 \mathrm{~nm}$} \\
\hline Main band $\mathrm{cm}^{-1}$ & Spectral Range $\left(100-2500 \mathrm{~cm}^{-1}\right)$ & Pigment name & Compound & $\begin{array}{l}\text { Power density } \\
\mathrm{mW} \mu \mathrm{m}^{-2}\end{array}$ \\
\hline 92 & $315,949,179,1296,1436 \mathrm{br}$ & Verdigris & $\begin{array}{l}\text { Copper(II) acetate, } \mathrm{Cu}\left(\mathrm{CH}_{3} \mathrm{COO}\right)_{2} \\
{\left[\mathrm{Cu}(\mathrm{OH})_{2}\right]_{3} 2 \mathrm{H}_{2} \mathrm{O}}\end{array}$ & 0.86 \\
\hline 105 & $74,1049,1053,416 \mathrm{br}, 679$ & White lead & $\begin{array}{l}\text { Basic lead(II) carbonate, } 2 \mathrm{~Pb} \mathrm{CO}_{3} \\
\mathrm{~Pb}(\mathrm{OH})_{2}\end{array}$ & 0.12 \\
\hline 120 & $\begin{array}{l}549,390,151,314,142 \mathrm{sh}, 230 \mathrm{br}, \\
63,85,454\end{array}$ & Minium/red lead & Lead (II, IV) oxide, $\mathrm{Pb}_{3} \mathrm{O}_{4}$ & 0.86 \\
\hline 128 (ref. 79) & $\begin{array}{l}79,196,{ }^{79} 457,{ }^{79} 292,{ }^{79} 273,{ }^{79} 112, \\
524,{ }^{79} 379,{ }^{79} 96,304,{ }^{79} 339,432\end{array}$ & Lead tin yellow & $\begin{array}{l}\text { Tin(II) sulfide, lead(II) stannate, } \\
\mathrm{Pb}_{2} \mathrm{SnO}_{4}\end{array}$ & 0.37 \\
\hline 142 & $87,289,70,384,217$ & Massicot & Lead(II) oxide, $\mathrm{PbO}$ & 0.37 \\
\hline 150 & $\begin{array}{l}179,77,218,269,430,1061 \mathrm{br} \\
1495\end{array}$ & Malachite & $\begin{array}{l}\text { Basic copper(II) carbonate, } \\
\mathrm{Cu}_{2} \mathrm{CO}_{3}(\mathrm{OH})_{2}\end{array}$ & 0.86 \\
\hline 254 (ref. 79) & $343,,^{79} 283,,^{79} 103,85,142$ & Vermillion & Synthetic mercury(II) sulfide, HgS & 0.12 \\
\hline 254 (ref. 79) & $343,,^{79} 283,{ }^{79} 103,,^{79} 85$ (ref. 79) & Cinnabar & Mercury(II) sulfide, $\mathrm{HgS}$ & 0.12 \\
\hline 287 & $222,406,605,489,241 \mathrm{sh}$ & Caput Mortuum & Iron(III) oxide, $\mathrm{Fe}_{2} \mathrm{O}_{3}$ & 2.85 \\
\hline 291 & $225,408,612,244,498,1321 \mathrm{br}$ & Haematite & Iron(III) oxide, $\mathrm{Fe}_{2} \mathrm{O}_{3}$ & 2.85 \\
\hline 292 & $610 \mathrm{br}, 225,390 \mathrm{br}, 725$ & Raw umber & $\begin{array}{l}\text { Iron(III) oxide, } \mathrm{Fe}_{2} \mathrm{O}_{3}+ \\
\text { Manganese(Iv) oxide, } \mathrm{MnO}_{2}\end{array}$ & 1.24 \\
\hline 293 & $405,398,221,608$ & Red ochre & Iron(III) oxide, $\mathrm{Fe}_{3} \mathrm{O}_{4}+$ clay + silica & 2.85 \\
\hline 353 & $\begin{array}{l}191,182,220,342,166,171,142 \\
367,374,328,123\end{array}$ & Realgar & Arsenic(II) sulfide, $\mathrm{As}_{4} \mathrm{~S}_{4}$ & 0.37 \\
\hline 354 & $\begin{array}{l}311,293,154,202,136,382, \\
369 \mathrm{sh}, 179,105,69\end{array}$ & Orpiment & Arsenic(III) sulfide, $\mathrm{As}_{2} \mathrm{~S}_{3}$ & 0.12 \\
\hline 401 & $248,1093,171(\mathrm{a})$ & Azurite & $\begin{array}{l}\text { Basic copper(II) carbonate, } \\
\left.\mathrm{Cu}_{3}\left(\mathrm{CO}_{3}\right)_{2}(\mathrm{OH})_{2}\right)\end{array}$ & 0.86 \\
\hline 488 & $\begin{array}{l}\text { 1275, } 1192,600 \mathrm{br}, 1333 \mathrm{br}, 887 \\
1080,432,528\end{array}$ & Orcein & Natural red $28, \mathrm{C}_{28} \mathrm{H}_{24} \mathrm{~N}_{2} \mathrm{O}_{7}$ & 1.24 \\
\hline 541 & & Ultramarine & $\begin{array}{l}\mathrm{Na}_{6} \mathrm{Ca}_{6}\left(\mathrm{Al}_{6} \mathrm{~S}_{\mathrm{I} 6} \mathrm{O}_{24}\right)\left(\mathrm{SO}_{4}, \mathrm{~S}, \mathrm{~S}_{2}, \mathrm{~S}_{3},\right. \\
\mathrm{cl}, \mathrm{OH})_{2}\end{array}$ & 8.69 \\
\hline 979 & (a) & Iron Gall ink & Ferric Gallate $\mathrm{C}_{21} \mathrm{H}_{15} \mathrm{FeO}_{15}$ & 8.69 \\
\hline 1007 & $\begin{array}{l}386,415,297,92,1134,1087,244, \\
496,550,617,669,145,1297,1434\end{array}$ & Yellow ochre & $\begin{array}{l}\text { Iron(III) oxide hydrate, } \mathrm{Fe}_{2} \mathrm{O}_{3} \mathrm{H}_{2} \mathrm{O} \\
+ \text { clay + silica }\end{array}$ & 8.69 \\
\hline 1037 & $1596 \mathrm{br}$ & Lamp black & Carbon, $\mathrm{C}$ & 0.37 \\
\hline $1298 \mathrm{br}$ & $1550 \mathrm{br}$ & Bistre & Wood soot, carbon C & 1.24 \\
\hline $1300 \mathrm{br}$ & $1554 \mathrm{br}$ & Sepia & Melanin $\mathrm{C}_{18} \mathrm{H}_{10} \mathrm{~N}_{2} \mathrm{O}_{4}$ & 0.86 \\
\hline 1307 & $1593 \mathrm{br}$ & Ivory black & $\begin{array}{l}\text { Calcium hydroxide phosphate, } \\
\mathrm{Ca}_{5}(\mathrm{OH})\left(\mathrm{PO}_{4}\right)_{3}+\text { carbon, C }\end{array}$ & 0.86 \\
\hline 1309 & $1589 \mathrm{br}$ & Carbon black & Carbon, C & 0.37 \\
\hline 1318 & $1292,1470 \mathrm{br}, 1448 \mathrm{br}$ & Purple madder & $\begin{array}{l}\text { Alizarin } \mathrm{C}_{14} \mathrm{H}_{8} \mathrm{O}_{4} \text { and purpurin } \\
\mathrm{C}_{14} \mathrm{H}_{8} \mathrm{O}_{5}\end{array}$ & 1.24 \\
\hline 1321 & $1472,1301 \mathrm{br}$ & Alizarin purple & Alizarin $\mathrm{C}_{14} \mathrm{H}_{8} \mathrm{O}_{4}$ & 0.12 \\
\hline 1472 & 1328,1187 & Alizarin crimson & Alizarin $\mathrm{C}_{14} \mathrm{H}_{8} \mathrm{O}_{4}$ & 0.37 \\
\hline 1571 & $\begin{array}{l}252,544,1582,133,101,265,275 \\
599,1224,1310,235,674,757, \\
182,635,1364,1460,172,310,73, \\
1015,1246,1625,1146,870,1702\end{array}$ & Indigo & Indigo, $\mathrm{C}_{16} \mathrm{H}_{10} \mathrm{~N}_{2} \mathrm{O}_{2}$ & 1.24 \\
\hline 1593 & $\begin{array}{l}1435,1632,1453 \mathrm{sh}, 1331,370 \\
1221,1247,1281\end{array}$ & Gamboge & Gambogic acid, $\mathrm{C}_{38} \mathrm{H}_{44} \mathrm{O}_{8}$ & 8.69 \\
\hline
\end{tabular}

the particles of azurite do not disperse the heat efficiently and the rate of heat inside the single grain is higher than the rate of heat outside, they thermo-degrade. ${ }^{86}$ Ultramarine (Fig. 16) can be identified by the strong band at $550 \mathrm{~cm}^{-1}$ using all excitation wavelengths. The absorption band at around $610 \mathrm{~nm}$ means that the $532 \mathrm{~nm}$ and $632 \mathrm{~nm}$ excitation sources, close to the electronic absorption wavelength, benefit from strong resonance enhancement and yield a progression of bands due to the bending of $\mathrm{S}_{3}{ }^{-} \cdot{ }^{87}$ Indeed, in the spectrum collected with the
$488 \mathrm{~nm}$ shows clearer a band at $584 \mathrm{~cm}^{-1}$ result of the $\mathrm{S}_{2}{ }^{-}$ vibration, which with the other sources appears only as a shoulder of the main peak at $550 \mathrm{~cm}^{-1}$.

\section{Brown pigment}

The only brown pigment investigated was raw umber (Fig. 13). It is a mixture of iron oxides and manganese oxides. Investigation at $830 \mathrm{~nm}$ shows bands at $292 \mathrm{~cm}^{-1}, 610 \mathrm{~cm}^{-1}$, 
Haematite $\left(\mathrm{Fe}_{2} \mathrm{O}_{3}\right)$

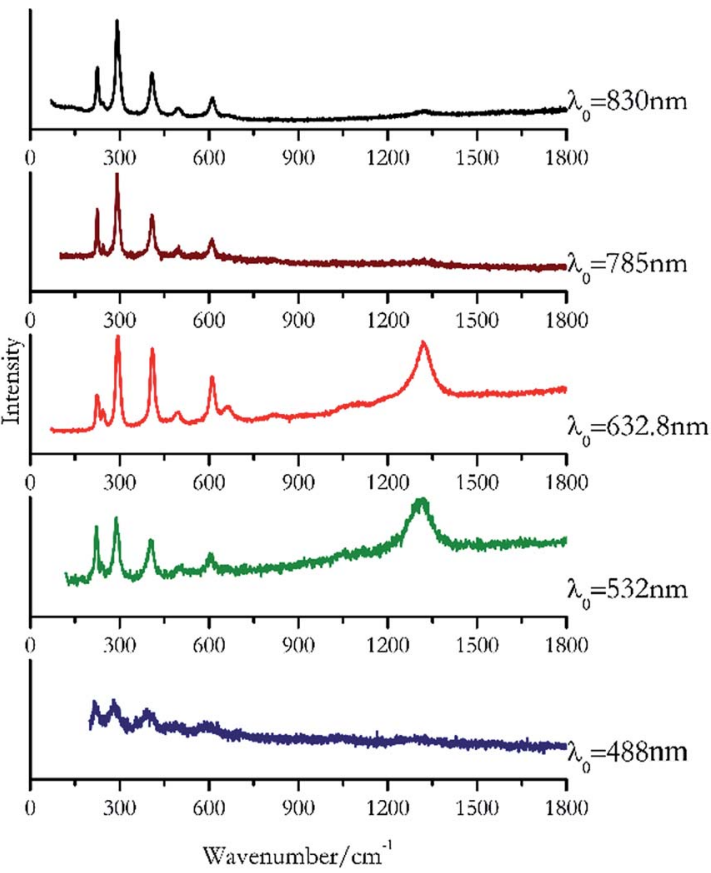

Fig. 2 Raman spectra of haematite.

$225 \mathrm{~cm}^{-1}, 390 \mathrm{~cm}^{-1}$ and $725 \mathrm{~cm}^{-1}$. Excitation with the green laser presents weak bands at $268 \mathrm{~cm}^{-1}, 214 \mathrm{~cm}^{-1}$ and $582 \mathrm{~cm}^{-1}$. No satisfactory Raman spectra were obtained with the other laser excitation wavelengths, $488 \mathrm{~nm}, 632.8 \mathrm{~nm}, 785$ $\mathrm{nm}$ or $830 \mathrm{~nm}$.

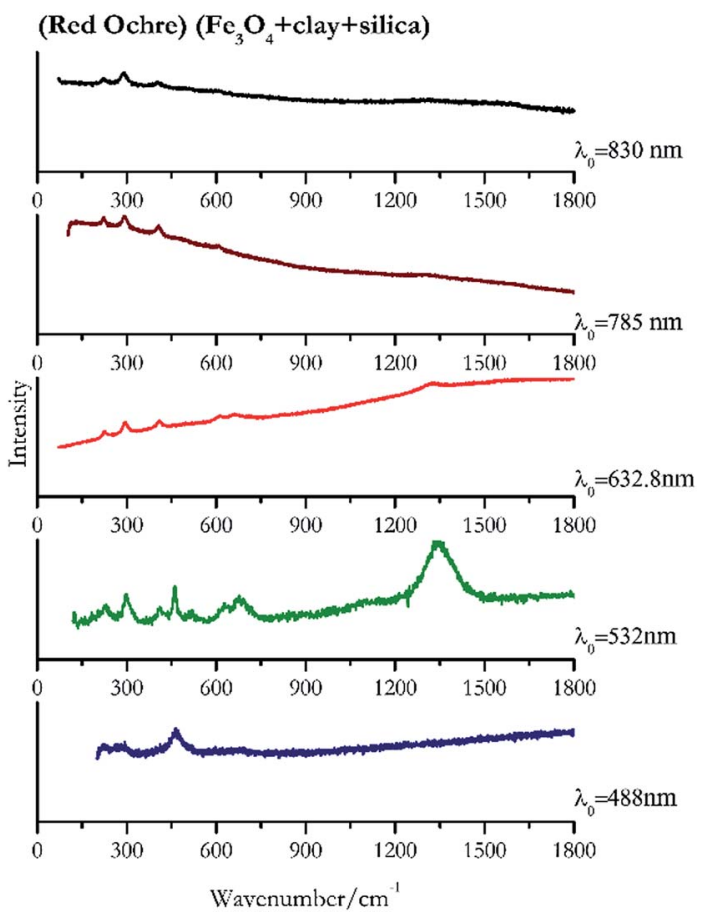

Fig. 3 Raman spectra of red ochre.

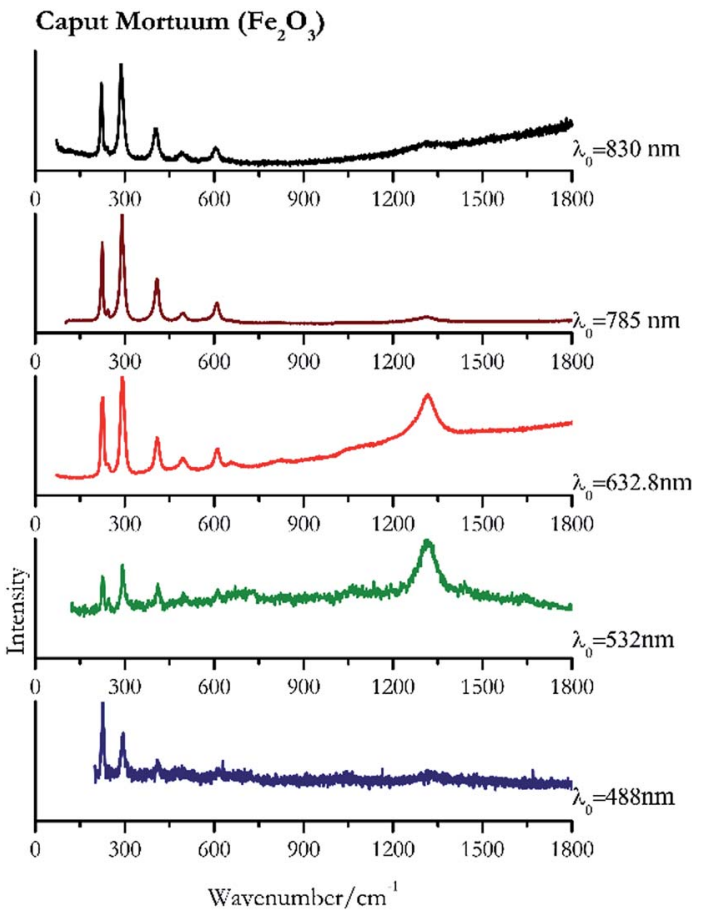

Fig. 4 Raman spectra of caput mortuum.

\section{Yellow pigments}

Orpiment (Fig. 17) is easily detectable with all the excitation wavelengths, requires only low laser powers to detect, and it may indeed cause saturation of the detector under some conditions. The main chromophore of yellow ochre is limonite, an iron oxy-hydroxide, and this pigment shows the same main

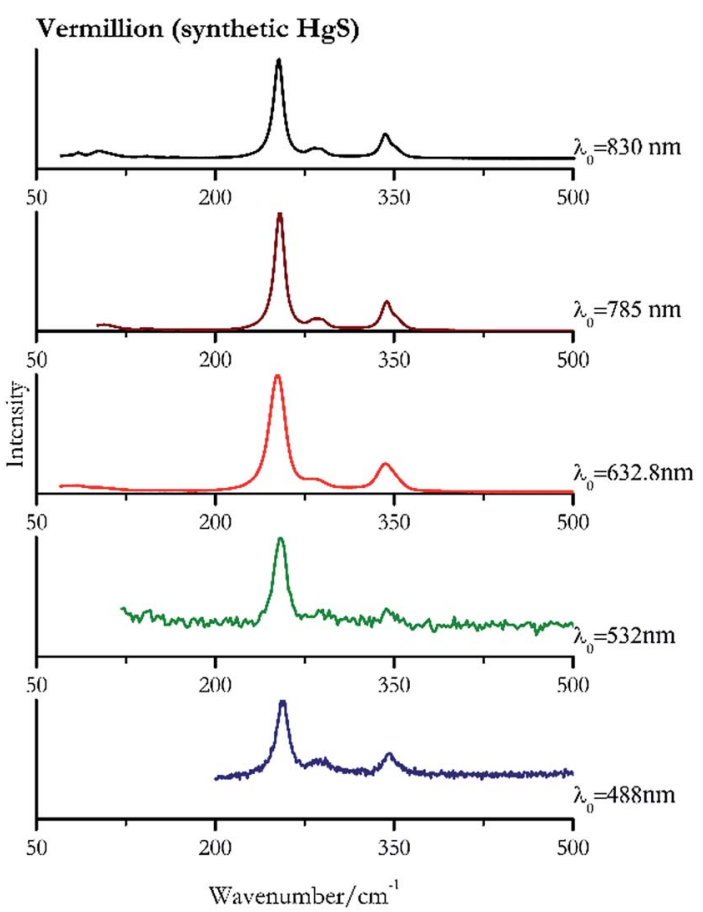

Fig. 5 Raman spectra of vermillion. 


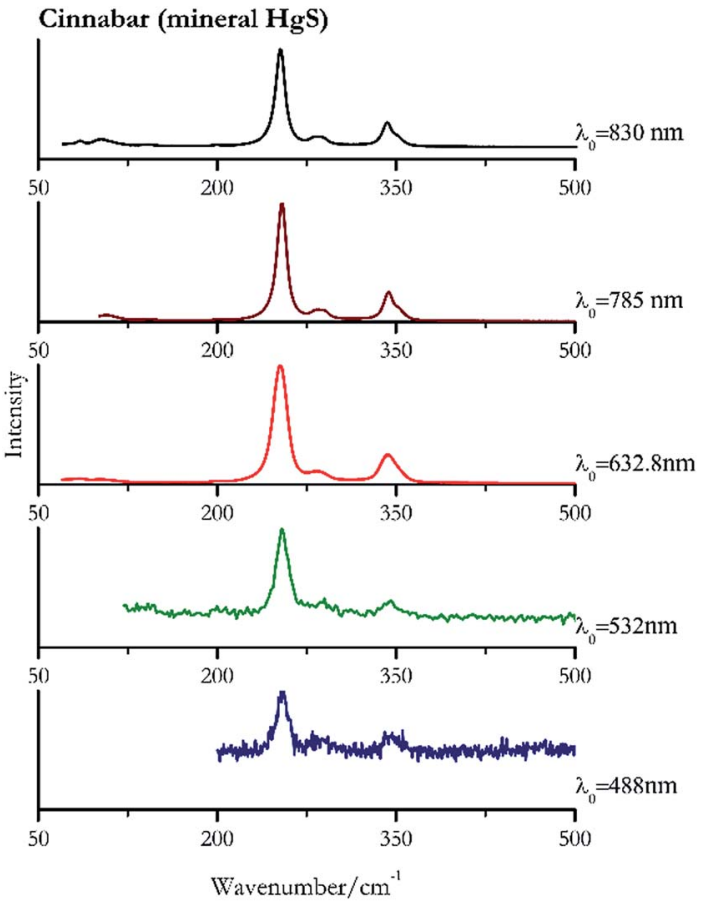

Fig. 6 Raman spectra of cinnabar.

peaks of the mineral at all wavelengths. Ochres come in a range of compositions, due to natural variance of the mineral and the Raman spectrum (Fig. 18) can therefore reflect these differences when collecting spectra from real historical artefacts. Lead tin yellow type I (Fig. 19) and massicot (Fig. 20) are both easily identified with the different laser wavelengths, but extra care

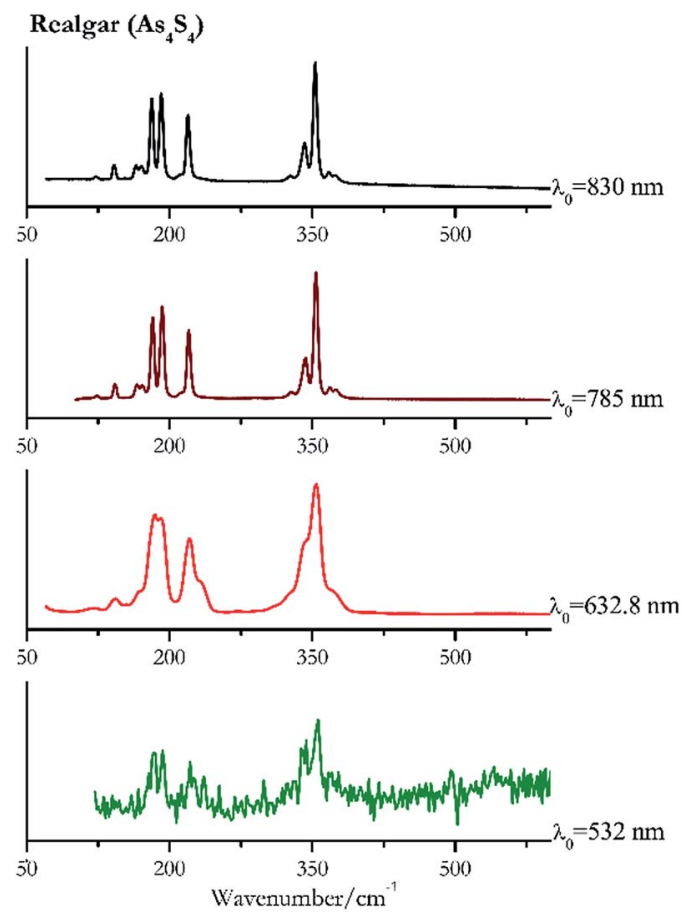

Fig. 7 Raman spectra of realgar.

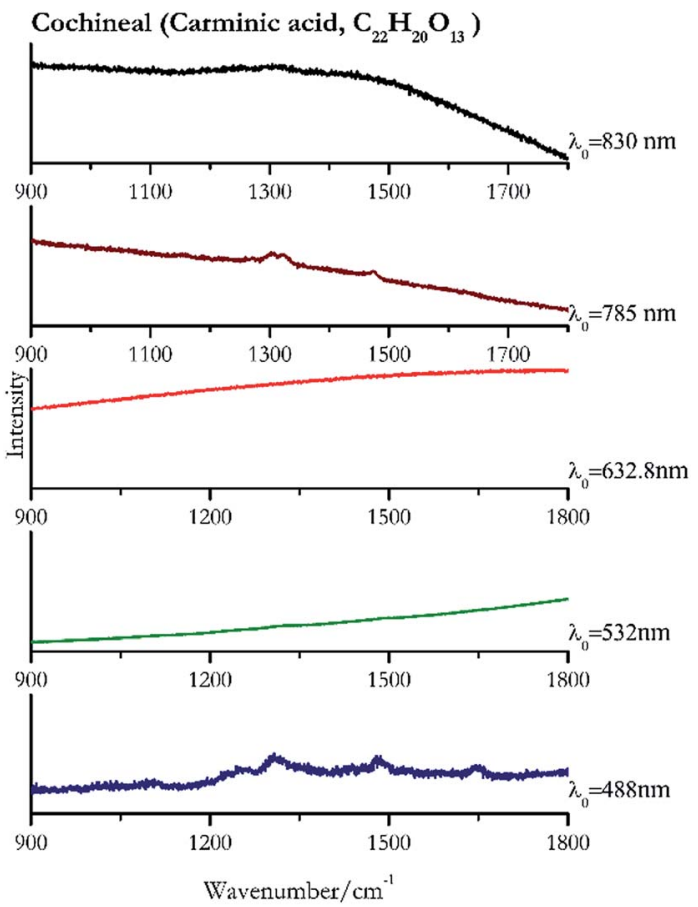

Fig. 8 Raman spectra of cochineal.

has to be taken since they are both lead compounds and careful management of the laser power is required to avoid photo degradation: Burgio records alteration at $10 \mathrm{~mW}$ with $514.5 \mathrm{~nm}$ excitation source. ${ }^{1}$ In the field, this simply requires using a reliable power meter prior to measurement to ensure one knows precisely the light power being delivered at the sample

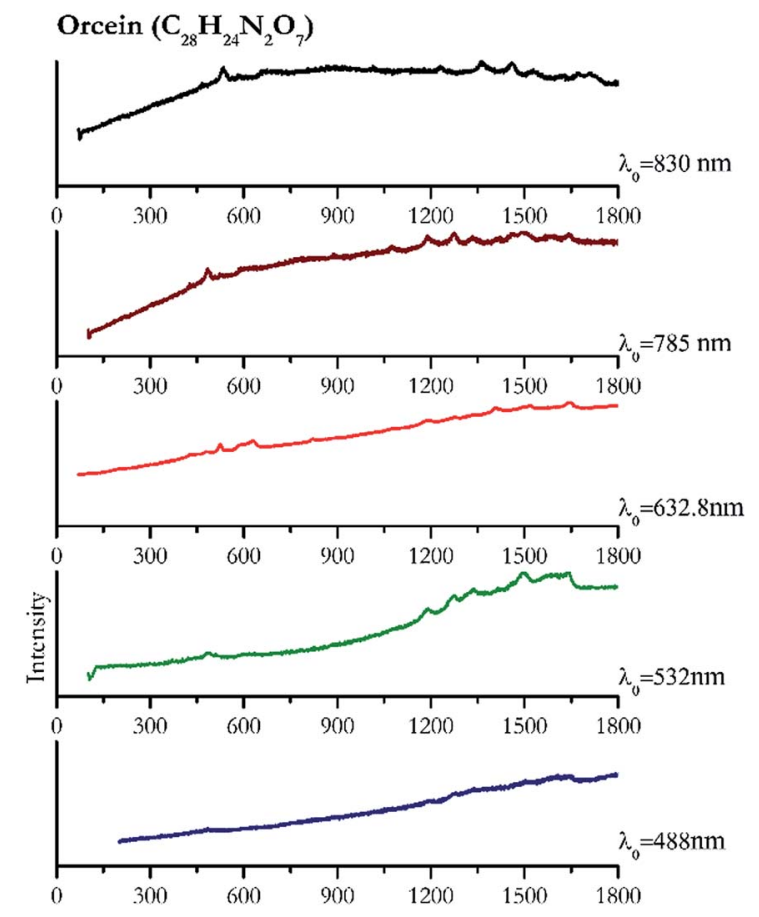

Fig. 9 Raman spectra of orcein. 


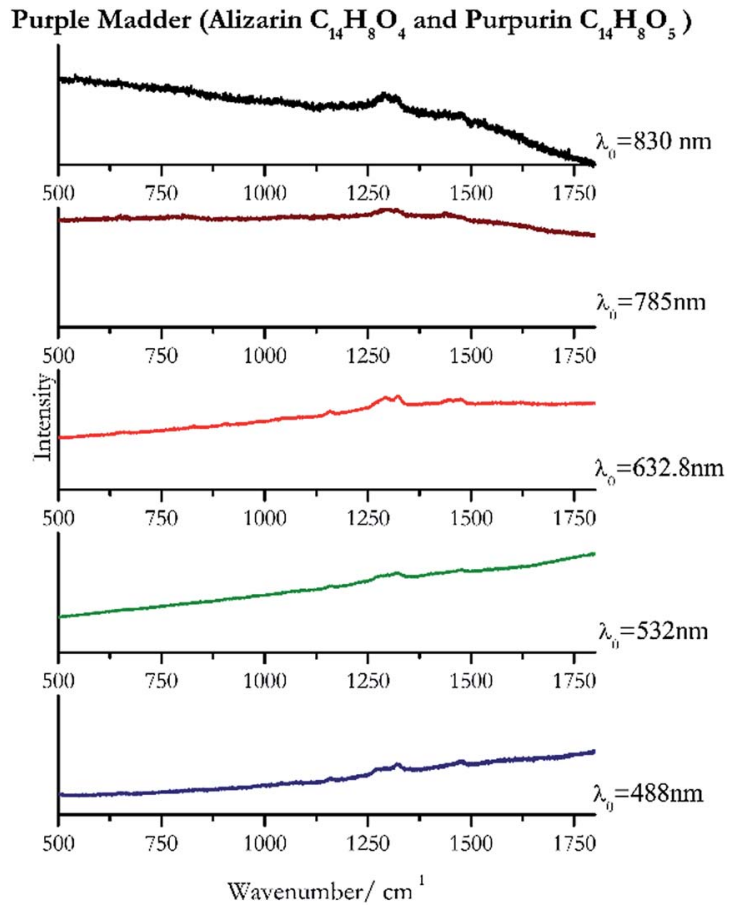

Fig. 10 Raman spectra of purple madder.

surface and to work well below the damage thresholds. Lead tin yellow (Fig. 19) and massicot (Fig. 20) were detected with the

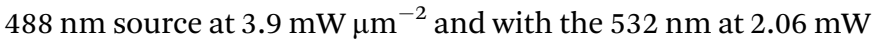
$\mu \mathrm{m}^{-2}$ for lead tin yellow type I and $0.82 \mathrm{~mW} \mu \mathrm{m}^{-2}$ for massicot, without any degradation. No damage at the sample was noticed with the higher wavelengths and if low values of power $(0.37$

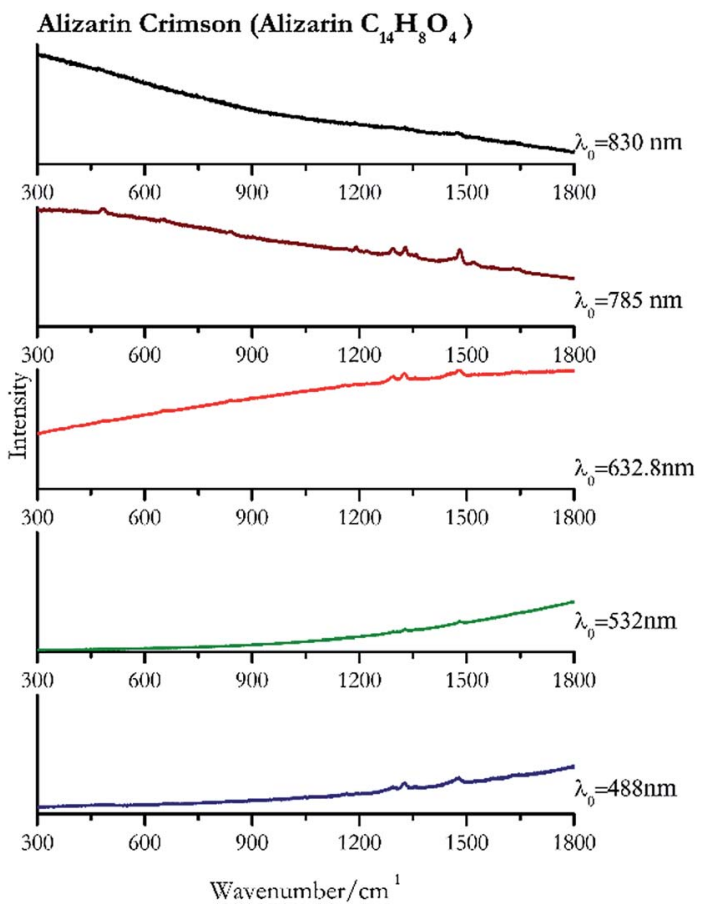

Fig. 11 Raman spectra of Alizarin crimson.

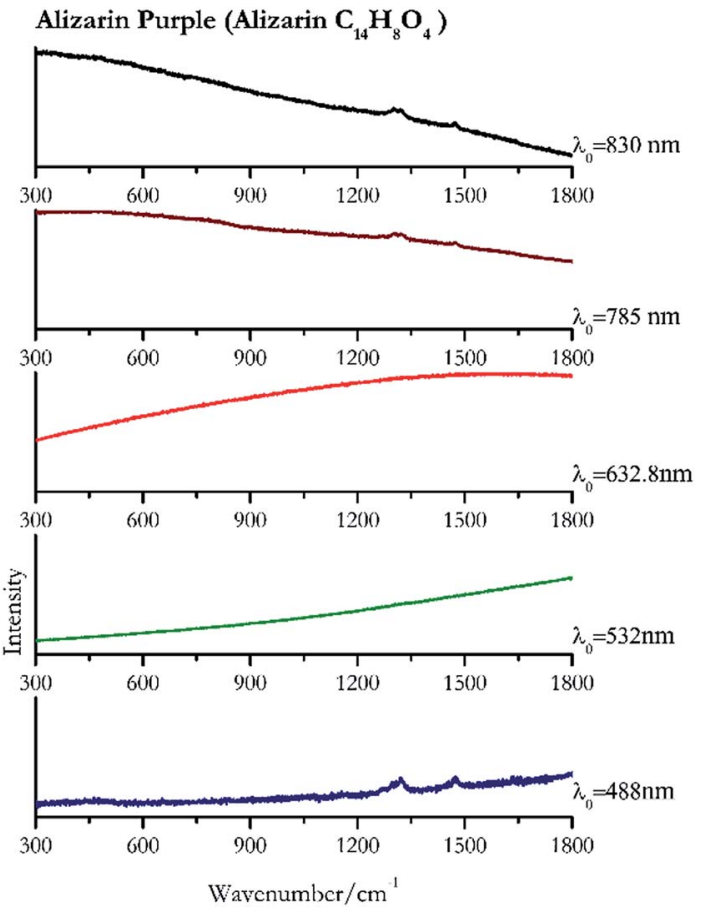

Fig. 12 Raman spectra of Alizarin purple.

$\mathrm{mW} \mu \mathrm{m}^{-2}$ with $830 \mathrm{~nm}$ laser) were used it was to avoid the detector saturation. The organic nature of gamboge (Fig. 21) causes fluorescence in the spectra, especially with higher frequency sources. The $830 \mathrm{~nm}$ laser is the one that yields the best spectrum, with an intense peak at $1593 \mathrm{~cm}^{-1}$.

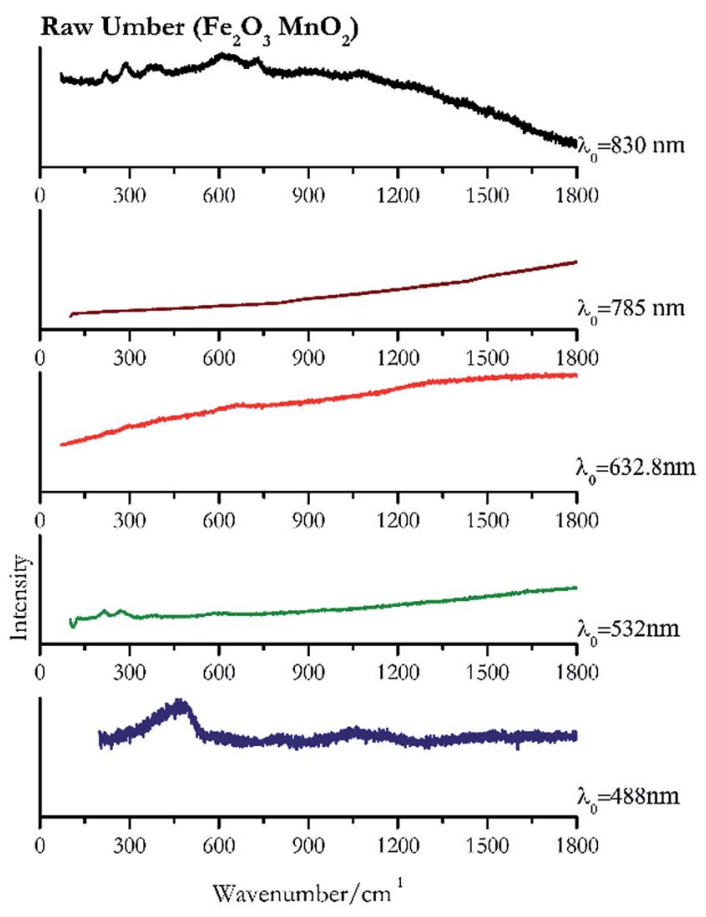

Fig. 13 Raman spectra of raw umber. 


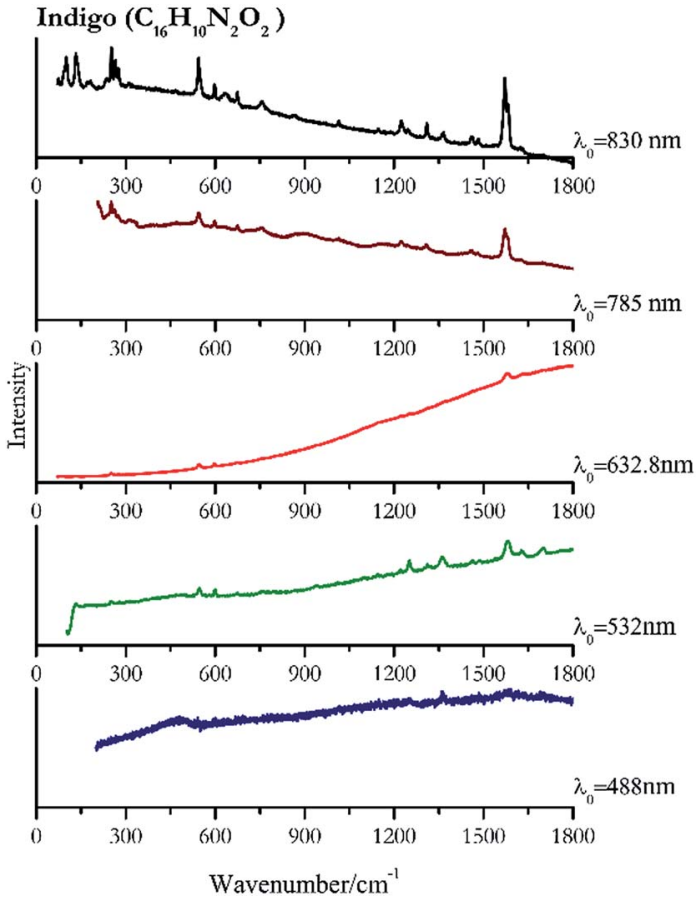

Fig. 14 Raman spectra of indigo.

\section{White pigment}

When suspecting the presence of white lead (Fig. 22) it is necessary to employ low laser power $\left(0.39 \mathrm{~mW} \mathrm{\mu m}^{-2}\right.$ with
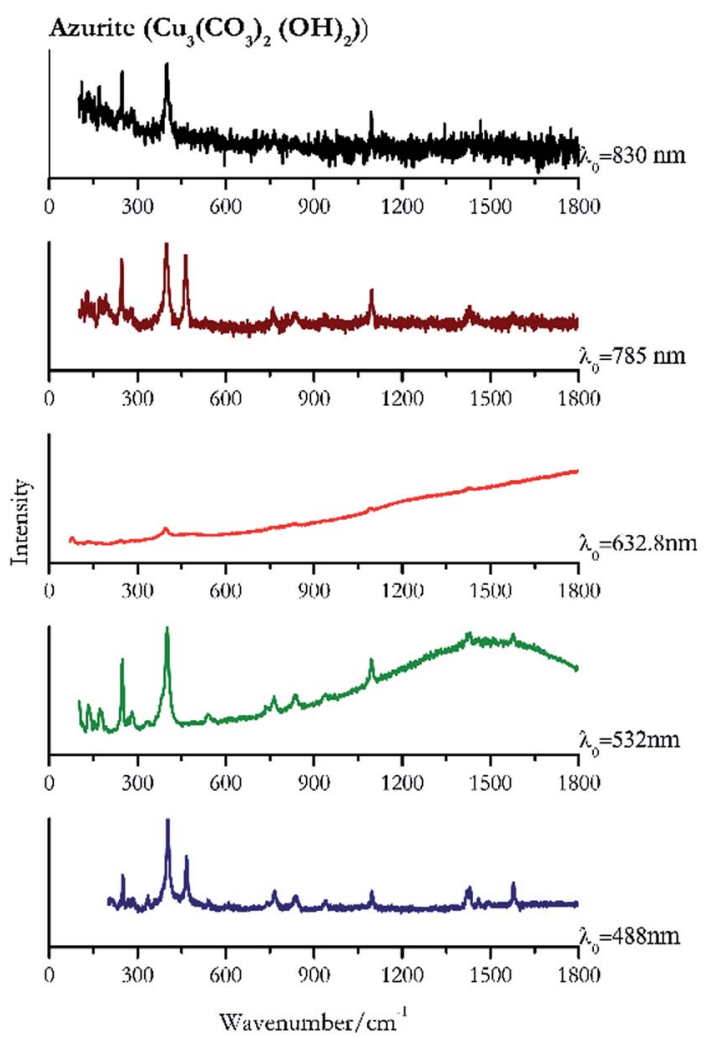

Fig. 15 Raman spectra of azurite.

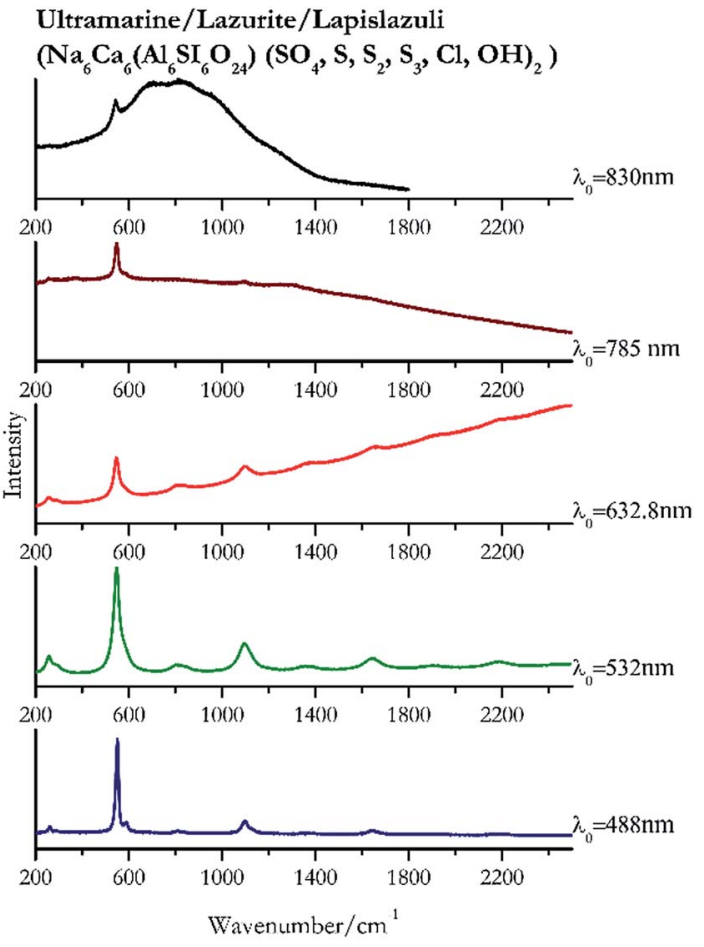

Fig. 16 Raman spectra of ultramarine.

$488 \mathrm{~nm}$ and $0.12 \mathrm{~mW} \mu \mathrm{m}^{-2}$ with $830 \mathrm{~nm}$ ) because like other lead compounds it can easily be photodegraded by the laser. ${ }^{88,89}$ The highest intensity peak is observed at $104 \mathrm{~cm}^{-1}$ that requires a good laser light rejection cut off filter. As it can be seen from

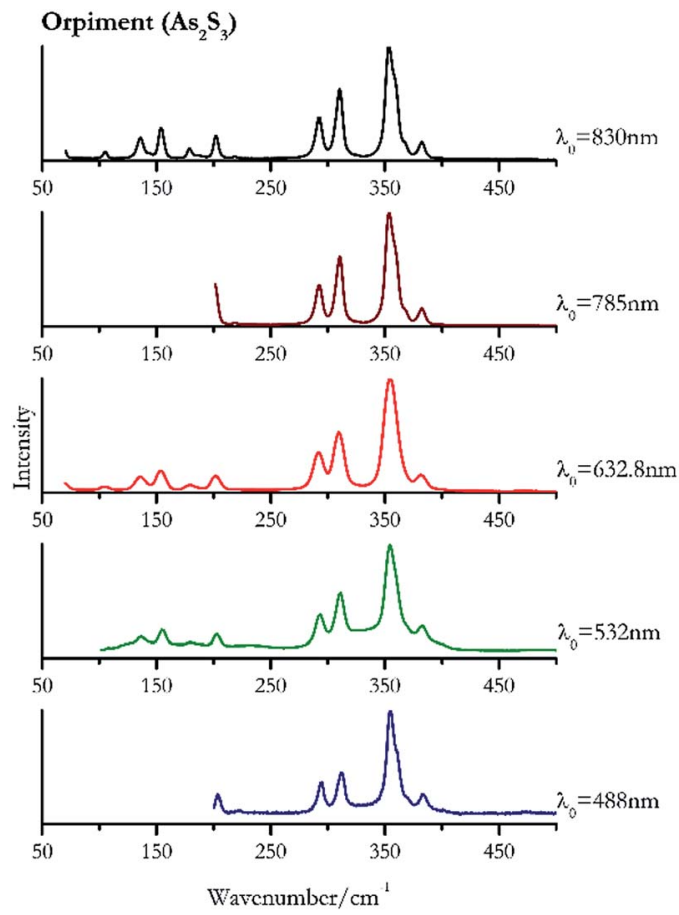

Fig. 17 Raman spectra of orpiment. 


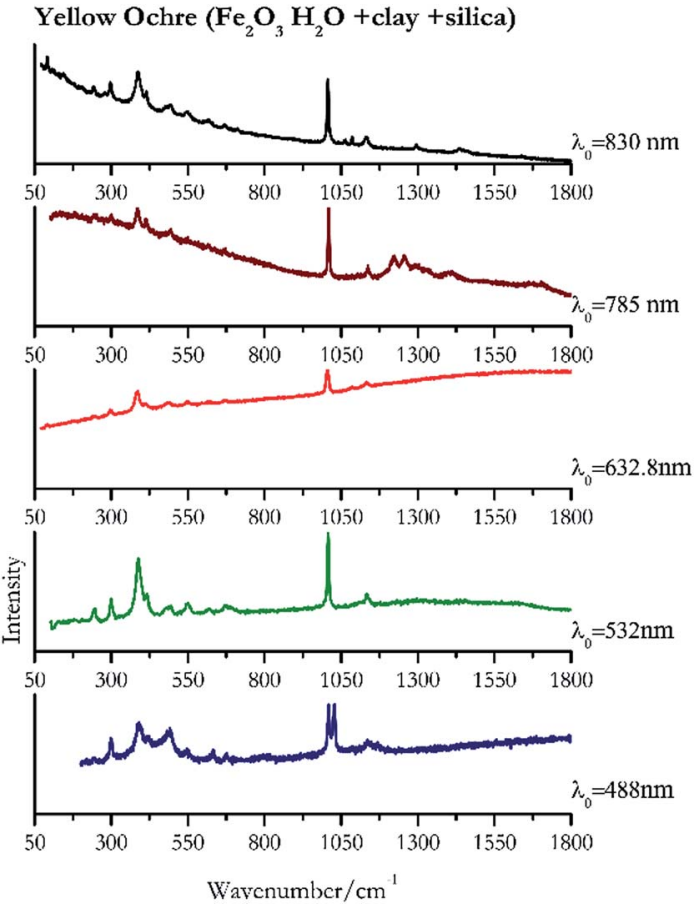

Fig. 18 Raman spectra of yellow ochre.

the spectra presented in Fig. 22 this band is clearly observed in our system when using the $632.8 \mathrm{~nm}$ excitation, where the notch filter has a shorter cut off. However, it remains observable using $830 \mathrm{~nm}$ excitation source, but lies on top of the sloping laser beam profile.

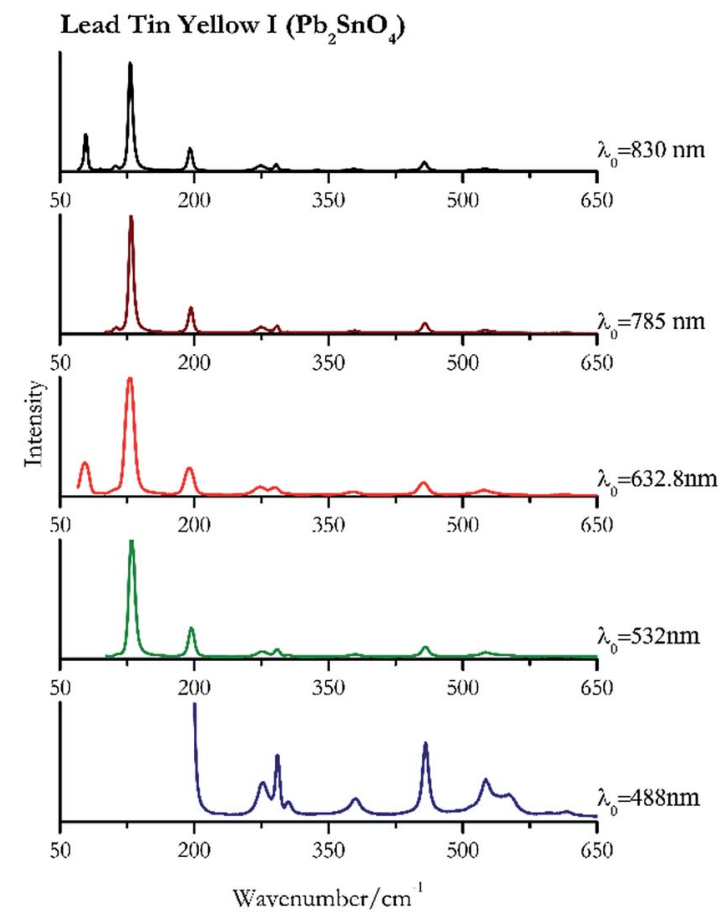

Fig. 19 Raman spectra of lead tin yellow I.

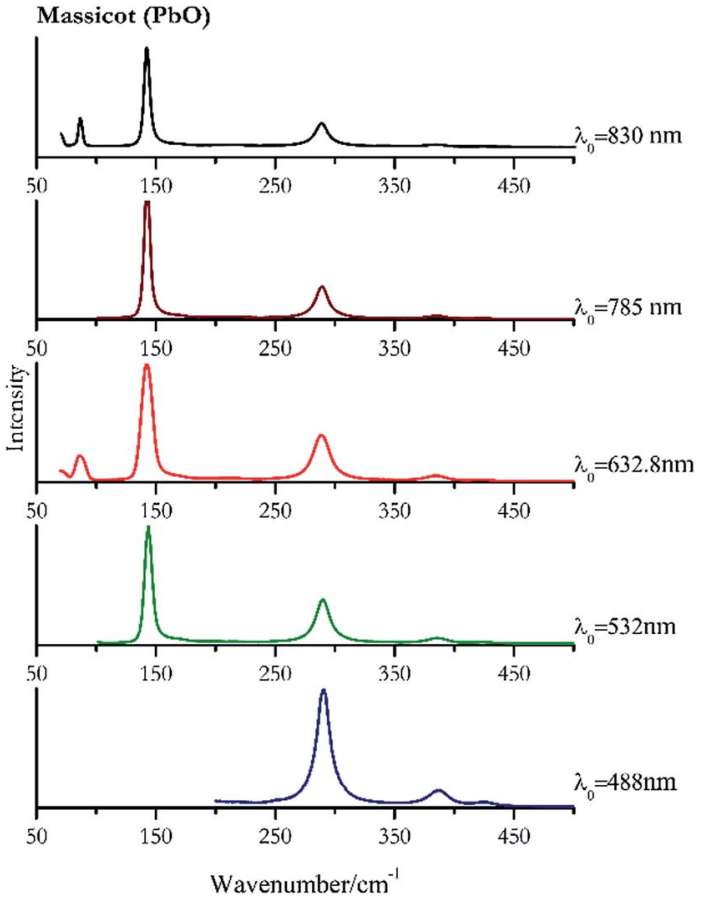

Fig. 20 Raman spectra of massicot.

\section{Green pigments}

Verdigris (Fig. 23) and malachite (Fig. 24) both result in good Raman spectra for the shorter wavelengths and do not provide a spectrum with the $785 \mathrm{~nm}$ laser because of strong absorption of the light in this region. ${ }^{\mathbf{8 4}}$ However, the spectra

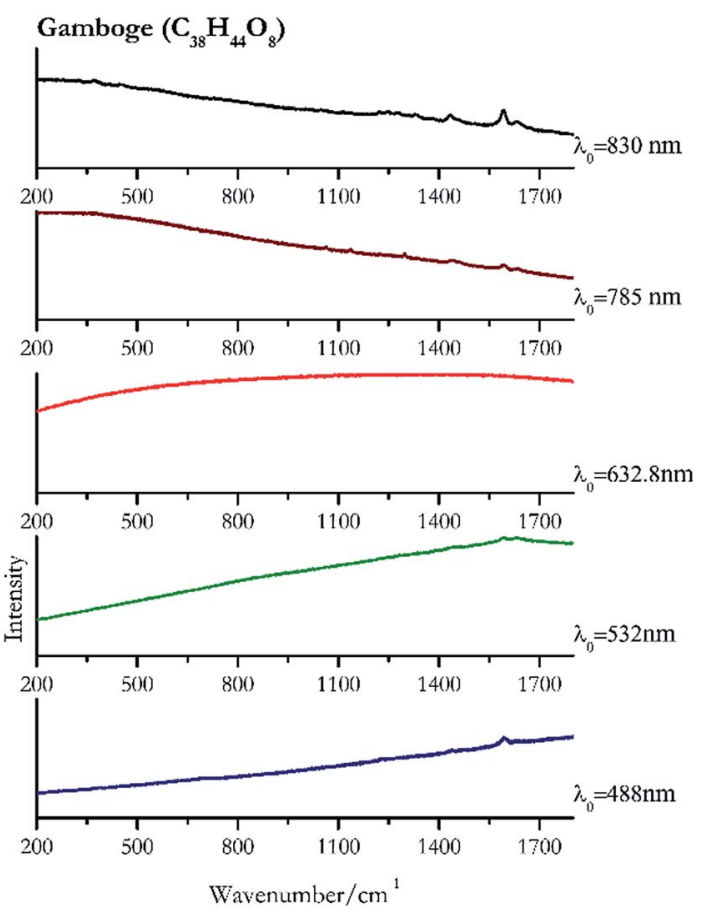

Fig. 21 Raman spectra of gamboge. 
White Lead $\left.\left(2 \mathrm{~Pb} \mathrm{CO} \mathrm{Cb}_{3} \mathrm{OH}\right)_{2}\right)$
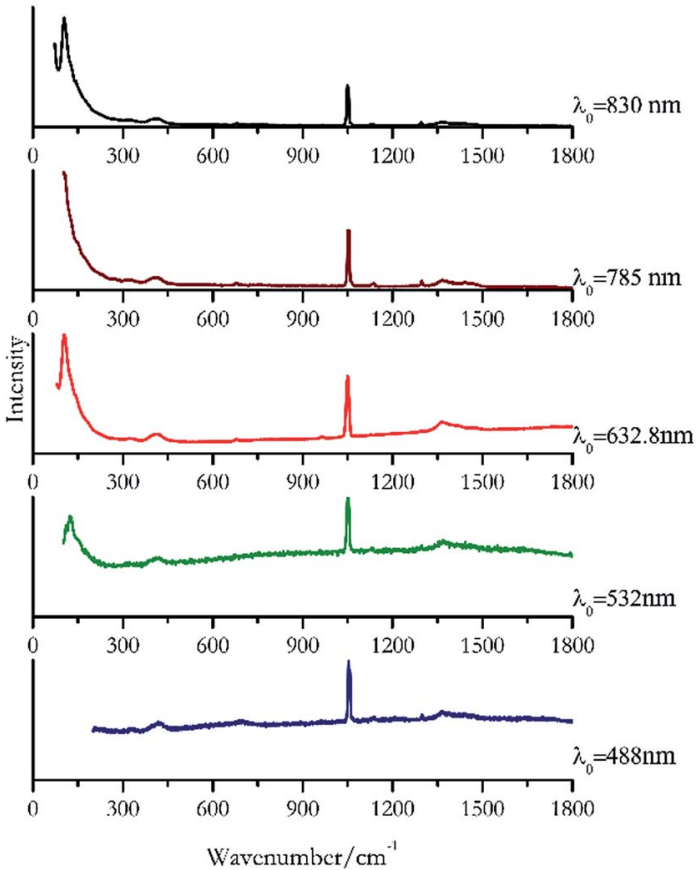

Fig. 22 Raman spectra of white lead.

obtained with the $830 \mathrm{~nm}$ do present peaks at $150 \mathrm{~cm}^{-1}$, $179 \mathrm{~cm}^{-1}, 218 \mathrm{~cm}^{-1}, 269 \mathrm{~cm}^{-1}$ to identify the pigments unambiguously.
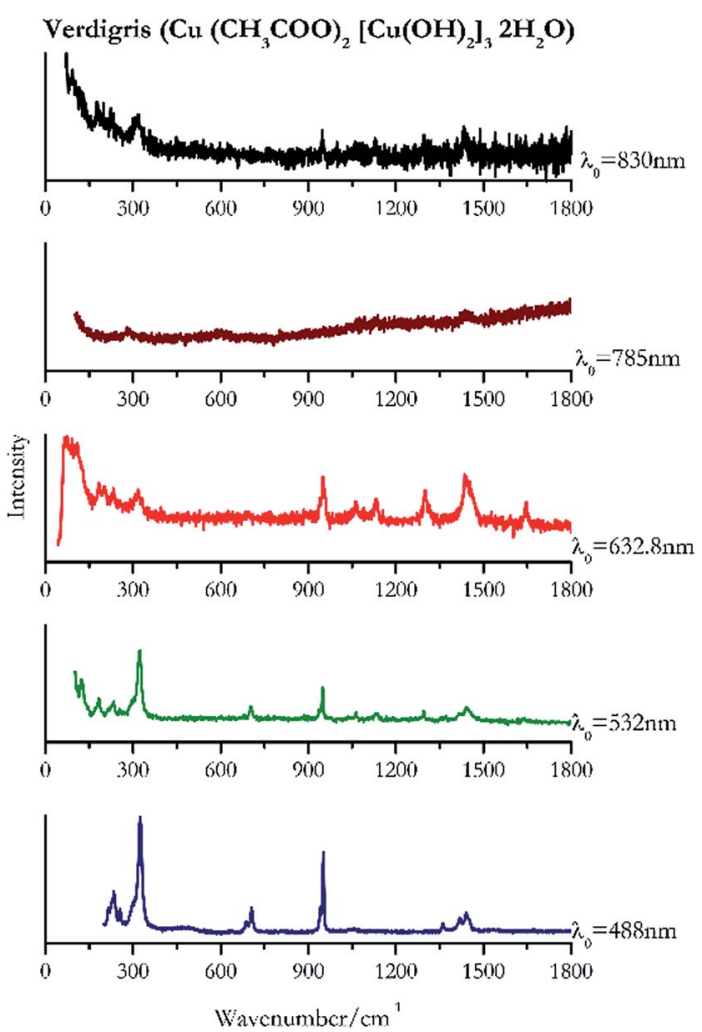

Fig. 23 Raman spectra of verdigris.

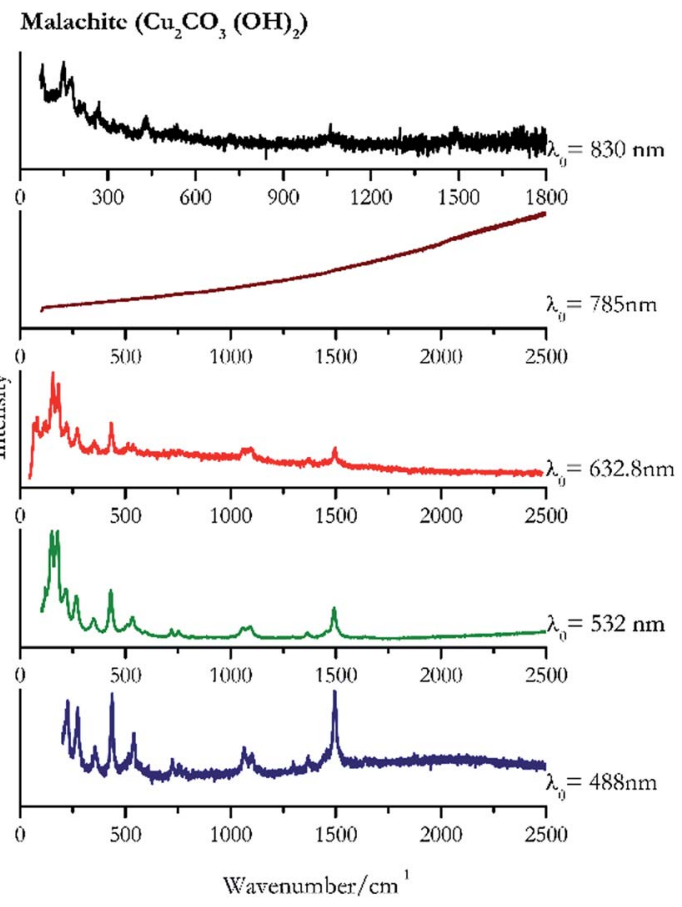

Fig. 24 Raman spectra of malachite.

Black pigments and inks

Carbon black, ivory black, lamp black and bistre (Fig. 25, 26, 27 and 28 respectively) are all characterized by broad bands between $1300 \mathrm{~cm}^{-1}$ and $1600 \mathrm{~cm}^{-1}$ due to the amorphous carbon. It is not possible to distinguish one from the others

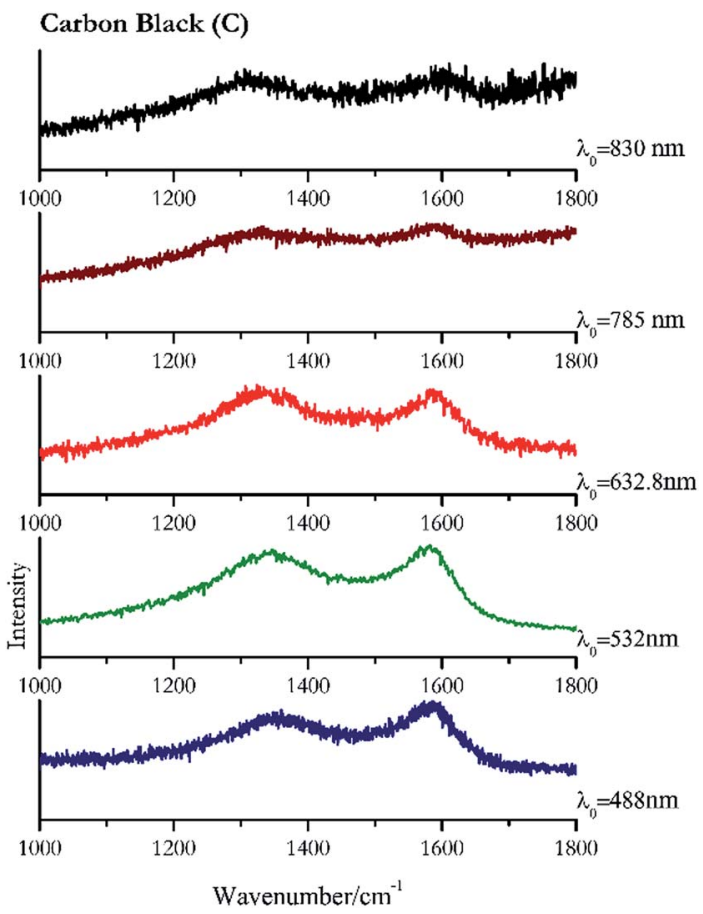

Fig. 25 Raman spectra of carbon black. 


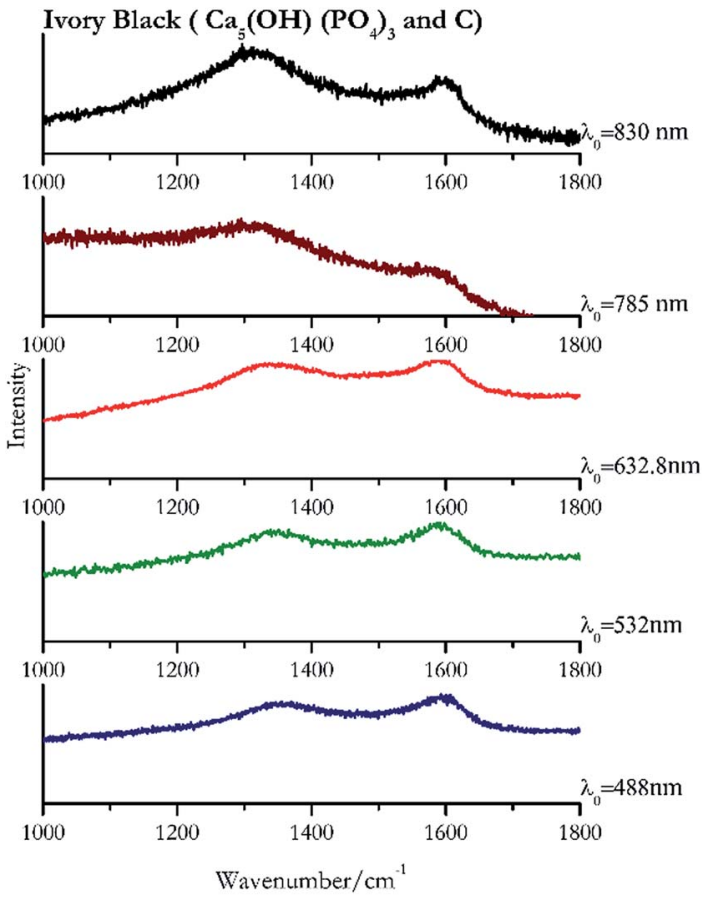

Fig. 26 Raman spectra of ivory black.

using a Raman spectroscopy. ${ }^{91}$ In a previous work a band at $965 \mathrm{~cm}^{-1}$ is recorded for ivory black, but it is not present in these spectra. The $785 \mathrm{~nm}$ laser seemed to be the one that provided the less intense peaks for all these black pigments. The sepia also shows two broad bands (Fig. 29), but they are generated by melanin, the main constituent of the

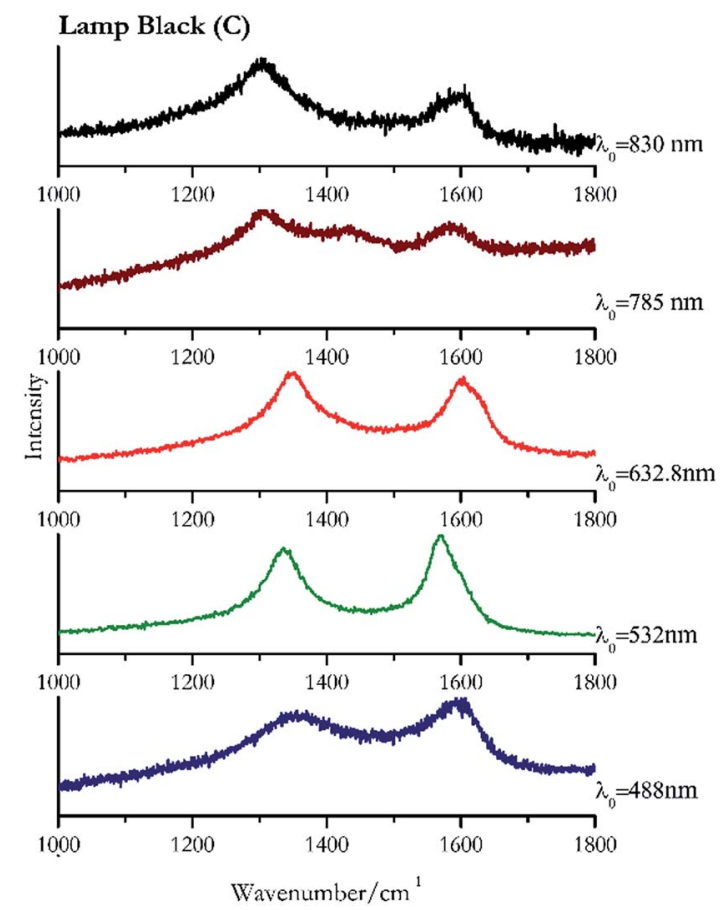

Fig. 27 Raman spectra of lamp black.
Bistre (Wood soot)

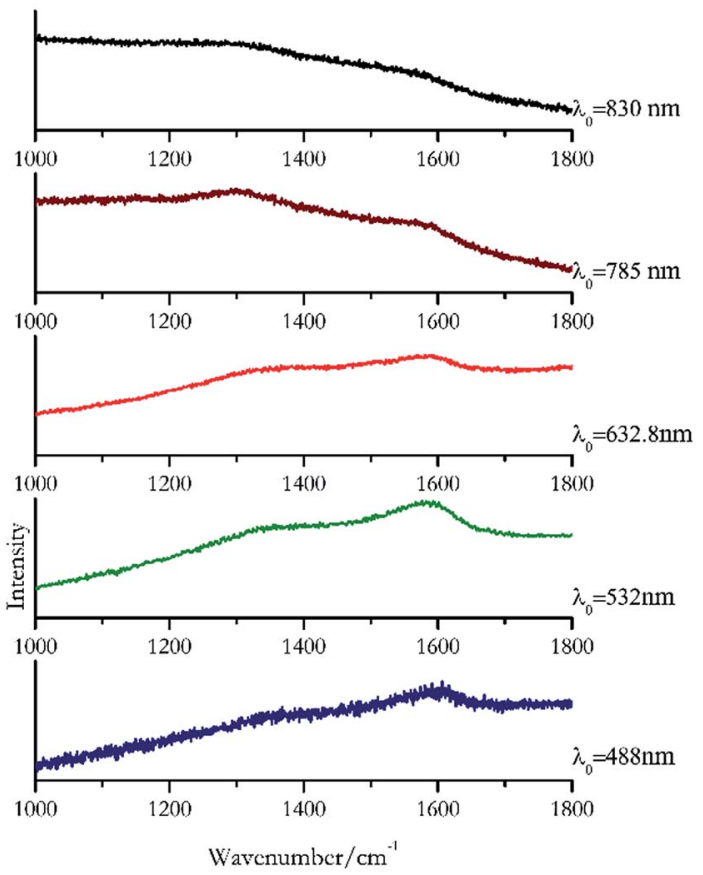

Fig. 28 Raman spectra of bistre.

pigment. ${ }^{92,93}$ Iron gall ink presents a peak at circa $980 \mathrm{~cm}^{-1}$ in the spectra collected (Fig. 30) with the two NIR sources, then a broad band in between 560 and $570 \mathrm{~cm}^{-1}$ that can be observed in the 532 and $785 \mathrm{~nm}$ spectra, as well as one at about $1350 \mathrm{~cm}^{-1}$. The spectrum acquired with the green laser

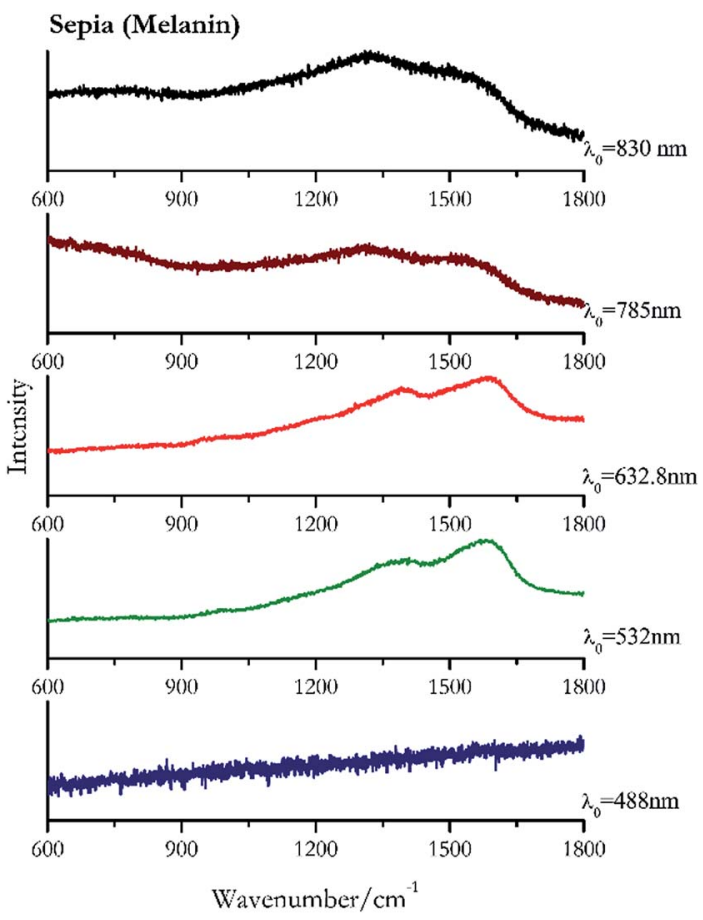

Fig. 29 Raman spectra of sepia. 


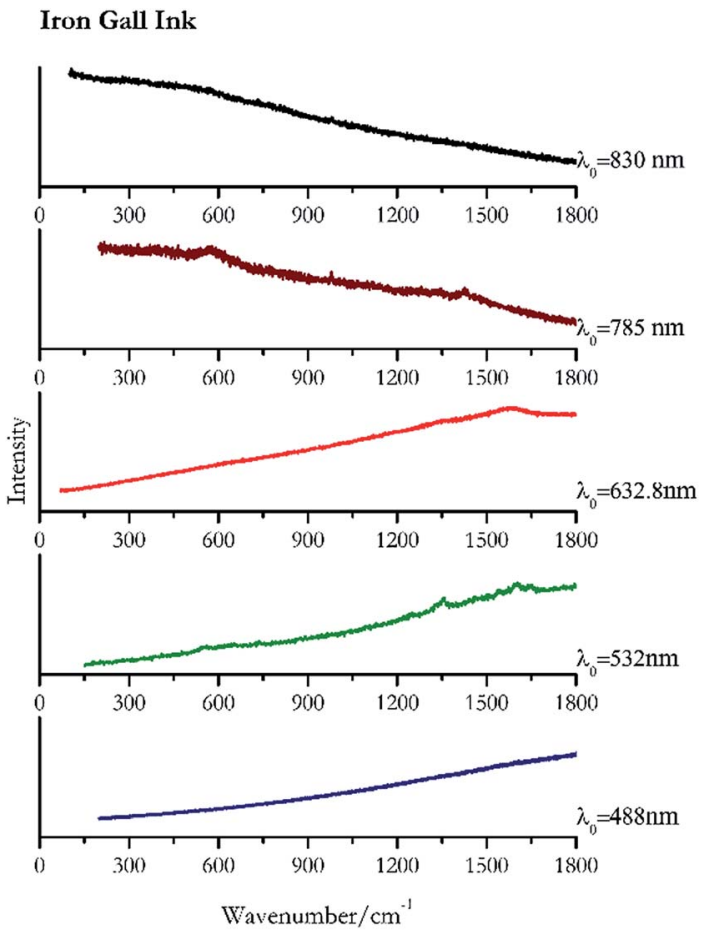

Fig. 30 Raman spectra of iron gall ink.

has also peaks at $1601 \mathrm{~cm}^{-1}$ and $1644 \mathrm{~cm}^{-1}$. Historically better spectra have been obtained for this pigment, ${ }^{\mathbf{9 4}}$ however we were not able to reproduce these results at the lower power densities. Caput mortuum (Fig. 4) has been already considered among the iron oxide based red pigments.

\section{Conclusions}

This work seeks to provide an updated and useful reference handbook for identification by Raman spectroscopy of pigments of the middle ages meeting the needs of researchers working with portable equipment in situ and the increase in the availability of different wavelength lasers. Table 1 helps in choosing the best excitation wavelength to investigate expected pigments on a specific artefact. Indeed, the discussion of the spectra calls attention to the different phenomena that can occur according to the nature of the pigment and the wavelength used to investigate it, for example in considering the resonance Raman condition and how this effects relative peak intensities in comparison to normal Raman effect. The collection of spectra helps to compare the experimental data with references acquired with the same laser source, to unequivocally identify the pigment. The Tables 2-6 provide a practical guide, which in few steps allows the identification of pigments. Since the intensities of peaks vary according to the exciting source, the operator can search references recorded with the same wavelength used during the measurements. New pigment references collected with wavelengths not used in previous works are also provided. This work also concludes that it is evident that the Raman technique alone is not capable of fully characterizing all the pigments selected, especially the fluorescent organic dyes that are presenting challenges to curators. This highlights the need to turn to other techniques that can provide complementary information.

\section{Conflicts of interest}

There are no conflicts to declare.

\section{Acknowledgements}

The authors would like to thank the Northumbria University, Durham University and Rutherford Appleton Laboratory, Harwell Campus, Didcot. G. Marucci is also thankful to C. Aibéo, Rathgenforschungslabor (Berlin), for her advice. Funding for this project was provided through EPSRC DTA studentship at Northumbria University, STFC for instrument time at Harwell, and kind donations from Rob and Felicity Shepherd.

\section{Notes and references}

1 L. Burgio, R. J. H. Clark and S. Firth, Analyst, 2001, 126, 222227.

2 M. Aceto, A. Agostino, G. Fenoglio, M. Gulmini, V. Bianco and E. Pellizzi, Spectrochim. Acta, Part A, 2012, 91, 352-359.

3 J. Aramendia, L. Gomez-Nubla, K. Castro, I. MartinezArkarazo, D. Vega, A. Sanz López de Heredia, A. García Ibáñez de Opakua and J. Madariaga, J. Raman Spectrosc., 2012, 43, 1111-1117.

4 C. Boschetti, A. Corradi and P. Baraldi, J. Raman Spectrosc., 2008, 39, 1085-1090.

5 P. Colomban, J. Cult. Herit., 2008, 9, E55-E60.

6 P. Colomban, J. Raman Spectrosc., 2012, 43, 1529-1535.

7 P. Colomban, V. Milande and L. Le Bihan, J. Raman Spectrosc., 2004, 35, 527-535.

8 P. Colomban, V. Milande and H. Lucas, J. Raman Spectrosc., 2004, 35, 68-72.

9 P. Colomban and A. Tournie, J. Cult. Herit., 2007, 8, 242-256.

10 P. Colomban, A. Tournie, M. C. Caggiani and C. Paris, J. Raman Spectrosc., 2012, 43, 1975-1984.

11 C. Colombo, F. Bevilacqua, L. Brambilla, C. Conti, M. Realini, J. Striova and G. Zerbi, Anal. Bioanal. Chem., 2011, 401, 757-765.

12 D. de Waal, J. Raman Spectrosc., 2009, 40, 2162-2170.

13 M. K. Donais, D. George, B. Duncan, S. M. Wojtas and A. M. Daigle, Anal. Methods, 2011, 3, 1061-1071.

14 D. Hutsebaut, P. Vandenabeele and L. Moens, Analyst, 2005, 130, 1204-1214.

15 B. Kirmizi, P. Colomban and M. Blanc, J. Raman Spectrosc., 2010, 41, 1240-1247.

16 B. Kirmizi, P. Colomban and B. Quette, J. Raman Spectrosc., 2010, 41, 780-790.

17 D. Lauwers, A. G. Hutado, V. Tanevska, L. Moens, D. Bersani and P. Vandenabeele, Spectrochim. Acta, Part A, 2014, 118, 294-301.

18 D. Mancini, A. Tournie, M. C. Caggiani and P. Colomban, J. Raman Spectrosc., 2012, 43, 294-302. 
19 M. Pérez-Alonso, K. Castro, I. Martinez-Arkarazo, M. Angulo, M. Olazabal and J. Madariaga, Anal. Bioanal. Chem., 2004, 379, 42-50.

20 I. Reiche and L. Lambacher, J. Raman Spectrosc., 2004, 35, 719-725.

21 P. Ricciardi, P. Colomban, A. Tournie, M. Macchiarola and N. Ayed, J. Archaeol. Sci., 2009, 36, 2551-2559.

22 P. Ropret and J. M. Madariaga, J. Raman Spectrosc., 2014, 45, 985-992.

23 F. Rosi, V. Manuali, T. Grygar, P. Bezdicka, B. G. Brunetti, A. Sgamellotti, L. Burgio, C. Seccaronif and C. Miliani, J. Raman Spectrosc., 2011, 42, 407-414.

24 D. C. Smith, Spectrochim. Acta, Part A, 2003, 59, 2353-2369.

25 A. Tournie, L. C. Prinsloo, C. Paris, P. Colomban and B. Smith, J. Raman Spectrosc., 2011, 42, 399-406.

26 P. Vandenabeele, K. Castro, M. Hargreaves, L. Moens, J. M. Madariaga and H. G. M. Edwards, Anal. Chim. Acta, 2007, 588, 108-116.

27 P. Vandenabeele, H. G. M. Edwards and J. Jehlicka, Chem. Soc. Rev., 2014, 43, 2628-2649.

28 P. Vandenabeele, F. Verpoort and L. Moens, J. Raman Spectrosc., 2001, 32, 263-269.

29 P. Vandenabeele, T. L. Weis, E. R. Grant and L. J. Moens, Anal. Bioanal. Chem., 2004, 379, 137-142.

30 M. A. Ziemann, J. Raman Spectrosc., 2006, 37, 1019-1025.

31 D. Bersani, C. Conti, P. Matousek, F. Pozzi and P. Vandenabeele, Anal. Methods, 2016, 8, 8395-8409.

32 R. J. H. Clark, Chem. Soc. Rev., 1995, 24, 187-196.

33 L. M. Proniewicz, C. Paluszkiewicz, A. WesełuchaBirczyńska, H. Majcherczyk, A. Barański and A. Konieczna, J. Mol. Struct., 2001, 596, 163-169.

34 P. Vandenabeele, B. Wehling, L. Moens, H. Edwards, M. De Reu and G. Van Hooydonk, Anal. Chim. Acta, 2000, 407, 261274.

35 T. D. Chaplin, R. J. Clark, D. Jacobs, K. Jensen and G. D. Smith, Anal. Chem., 2005, 77, 3611-3622.

36 A. S. Lee, P. J. Mahon and D. C. Creagh, Vib. Spectrosc., 2006, 41, 170-175.

37 I. M. Bell, R. J. H. Clark and P. J. Gibbs, Spectrochim. Acta, Part A, 1997, 53, 2159-2179.

38 M. Bouchard and D. C. Smith, Spectrochim. Acta, Part A, 2003, 59, 2247-2266.

39 L. Burgio and R. J. H. Clark, Spectrochim. Acta, Part A, 2001, 57, 1491-1521.

40 M. Aceto, A. Agostino, G. Fenoglio, P. Baraldi, P. Zannini, C. Hofmann and E. Gamillscheg, Spectrochim. Acta, Part A, 2012, 95, 235-245.

41 D. Bersani, P. P. Lottici, F. Vignalil and G. Zanichelli, J. Raman Spectrosc., 2006, 37, 1012-1018.

42 S. P. Best, R. J. H. Clark, M. A. M. Daniels, C. A. Porter and R. Withnall, Stud. Conserv., 1995, 40, 31-40.

43 S. Bioletti, R. Leahy, J. Fields, B. Meehan and W. Blau, J. Raman Spectrosc., 2009, 40, 1043-1049.

44 K. L. Brown and R. J. H. Clark, J. Raman Spectrosc., 2004, 35, 4-12.

45 K. L. Brown and R. J. H. Clark, J. Raman Spectrosc., 2004, 35, 181-189.
46 K. L. Brown and R. J. H. Clark, J. Raman Spectrosc., 2004, 35, 217-223.

47 S. Bruni, S. Caglio, V. Guglielmi and G. Poldi, Appl. Phys. Mater. Sci. Process, 2008, 92, 103-108.

48 L. Burgio, D. A. Ciomartan and R. J. H. Clark, J. Raman Spectrosc., 1997, 28, 79-83.

49 G. Chapman, Manuscripta, 1986, 30, 168-169.

50 R. J. Clark, Chem. Soc. Rev., 1995, 24, 187-196.

51 R. J. H. Clark and P. J. Gibbs, J. Archaeol. Sci., 1998, 25, 621629.

52 R. J. H. Clark and J. van der Weerd, J. Raman Spectrosc., 2004, 35, 279-283.

53 M. Clarke, Stud. Conserv., 2004, 49, 231-244.

54 A. Deneckere, M. De Reu, M. P. J. Martens, K. De Coene, B. Vekemans, L. Vincze, P. De Maeyer, P. Vandenabeele and L. Moens, Spectrochim. Acta, Part A, 2011, 80, 125-132.

55 B. Doherty, A. Daveri, C. Clementi, A. Romani, S. Bioletti, B. Brunetti, A. Sgamellotti and C. Miliani, Spectrochim. Acta, Part A, 2013, 115, 330-336.

56 A. Duran, A. Lopez-Montes, J. Castaing and T. Espejo, J. Archaeol. Sci., 2014, 45, 52-58.

57 H. G. M. Edwards, D. W. Farwell, F. R. Perez and J. M. Garcia, Analyst, 2001, 126, 383-388.

58 D. Lauwers, V. Cattersel, L. Vandamme, A. Van Eester, K. De Langhe, L. Moens and P. Vandenabeele, J. Raman Spectrosc., 2014, 45, 1266-1271.

59 A. Le Gac, S. Pessanha, S. Longelin, M. Guerra, J. C. Frade, F. Lourenco, M. C. Serrano, M. Manso and M. L. Carvalho, Appl. Radiat. Isot., 2013, 82, 242-257.

60 K. Nesmerak and I. Nemcova, Anal. Lett., 2012, 45, 330-344.

61 K. Trentelman and N. Turner, J. Raman Spectrosc., 2009, 40, 577-584.

62 G. Van Der Snickt, W. De Nolf, B. Vekemans and K. Janssens, Appl. Phys. Mater. Sci. Process, 2008, 92, 59-68.

63 G. Van Hooydonk, M. De Reu, L. Moens, J. Van Aelst and L. Milis, Eur. J. Inorg. Chem., 1998, 639-644.

64 P. Vandenabeele, B. Wehling, L. Moens, B. Dekeyzer, B. Cardon, A. von Bohlen and R. Klockenkamper, Analyst, 1999, 124, 169-172.

65 B. Wehling, P. Vandenabeele, L. Moens, R. Klockenkamper, A. von Bohlen, G. Van Hooydonk and M. de Reu, Mikrochim. Acta, 1999, 130, 253-260.

66 A. Zoleo, L. Nodari, M. Rampazzo, F. Piccinelli, U. Russo, C. Federici and M. Brustolon, Archaeometry, 2014, 56, 496512.

67 C. Cennini, Il libro dell'arte, a cura di Fabio Frezzato, ed. Neri Pozza, Vicenza, 3rd edn, 2006.

68 M. Fryling, C. J. Frank and R. L. McCreery, Appl. Spectrosc., 1993, 47, 1965-1974.

69 K. J. Frost and R. L. Mccreery, Appl. Spectrosc., 1998, 52, 1614-1618.

70 P. Vandenabeele and L. Moens, J. Raman Spectrosc., 2012, 43, 1545-1550.

71 R. L. McCreery, Raman Spectroscopy for Chemical Analysis, United States of America, 10th edn, 2000.

72 P. Vandenabeele, Practical Raman Spectroscopy: an introduction, 1st edn, 2013. 
73 J. D. Ingle Jr and S. R. Crouch, 1988, 141-142.

74 Presented in part at the Workshop on Preparation of Historical Lake Pigments 23-25 March 2011 Doerner Institut, Bayerische Staatsgemaeldesammlungen, Muenchen, Germany, 2011.

75 The Non-Destructive and in-situ identification of controlled drugs and narcotics, Horiba Scientific, France.

76 A. Coccato, D. Bersani, A. Coudray, J. Sanyova, L. Moens and P. Vandenabeele, J. Raman Spectrosc., 2016, 47, 1429-1443.

77 M. Caggiani, A. Cosentino and A. Mangone, Microchem. J., 2016, 129, 123-132.

78 D. Bikiaris, S. Daniilia, S. Sotiropoulou, O. Katsimbiri, E. Pavlidou, A. Moutsatsou and Y. Chryssoulakis, Spectrochim. Acta Mol. Biomol. Spectrosc., 2000, 56, 3-18.

79 D. Lau, C. Villis, S. Furman and M. Livett, Anal. Chim. Acta, 2008, 610, 15-24.

80 M. Leona, Proc. Natl. Acad. Sci. U. S. A., 2009, 106.

81 A. V. Whitney, R. P. Van Duyne and F. Casadio, J. Raman Spectrosc., 2006, 37, 993-1002.

82 F. Pozzi, J. R. Lombardi and M. Leona, Heritage Sci., 2013, 1, 1-8.

83 M. Caggiani, A. Cosentino and A. Mangone, Microchem. J., 2016, 129, 123-132.
84 A. Coccato, D. Bersani, A. Coudray, J. Sanyova, L. Moens and P. Vandenabeele, J. Raman Spectrosc., 2016, 47, 1429-1443.

85 A. Cosentino, Environ. Conserv. J., 2014, 2, 57-68.

86 E. Mattei, G. De Vivo, A. De Santis, C. Gaetani, C. Pelosi and

U. Santamaria, J. Raman Spectrosc., 2008, 39, 302-306.

87 R. Clark and M. Franks, Chem. Phys. Lett., 1975, 34, 69-72.

88 P. Pouli, D. C. Emmony, C. E. Madden and I. Sutherland, J. Cult. Herit., 2003, 4, 271-275.

89 C. Goodeve, Trans. Faraday Soc., 1937, 33, 340-347.

90 M. Leona, J. Stenger and E. Ferloni, J. Raman Spectrosc., 2006, 37.

91 E. P. Tomasini, E. B. Halac, M. Reinoso, E. J. Di Liscia and M. S. Maier, J. Raman Spectrosc., 2012, 43, 1671-1675.

92 S. A. Centeno and J. Shamir, J. Mol. Struct., 2008, 873, 149159.

93 Z. Huang, H. Lui, X. Chen, A. Alajlan, D. I. McLean and H. Zeng, J. Biomed. Optic., 2004, 9, 1198-1205.

94 M. Bicchieri, M. Monti, G. Piantanida and A. Sodo, All that is iron-ink is not always iron-gall!, 2008.

95 K. Trentelman, L. Stodulski and M. Pavlosky, Anal. Chem., 1996, 68(10), 1755-1761. 